\title{
Environmental conditions, fund characteristics, and Islamic orientation: An analysis of mutual fund performance for the MENA region ${ }^{\text {is }}$
}

\author{
Ahmed A. El-Masry a,b,c, Diego Víctor de Mingo-López ${ }^{\mathrm{d}}$, \\ Juan Carlos Matallín-Sáez ${ }^{\mathrm{d}}$, Emili Tortosa-Ausina ${ }^{\mathrm{d}, \mathrm{e}, *}$ \\ a Plymouth University, United Kingdom \\ b Mansoura University, Egypt \\ c Umm AlQura University, Saudi Arabia \\ d Universitat Jaume I, Spain \\ e Ivie, Spain
}

\section{A R T I C L E I N F O}

\section{Article history:}

Received 28 November 2014

Received in revised form 20 October 2016

Accepted 21 October 2016

Available online $\mathrm{xxx}$

\section{JEL classification:}

G11

G12

G14

G23

Keywords:

GCC

Islamic

MENA

Mutual fund

Performance

\begin{abstract}
A B S T R A C T
Islamic funds are increasingly seen as an alternative to conventional funds, in part due to the growing prominence of Islamic finance. In contrast to most previous literature, this paper focuses on the countries of the Middle East and North African region (MENA), and compares the performance of Islamic and conventional funds during crisis and recovery periods. Results show that the relative performance of Islamic and conventional funds seem to be conditioned by several factors such as the (geographical) context in which the investment is made. Considering the entire MENA region, Islamic funds perform, on average, slightly worse than conventional funds. However, if the analysis is restricted to Gulf Cooperation Council (GCC) countries, the result opposite is found. In addition, the performance gap between the two types of funds either widens or shrinks when considering recovery or crisis times, providing evidence that Islamic funds are more stable in times of distress.
\end{abstract} (C) 2016 Elsevier B.V. All rights reserved.

\section{Introduction}

In the wake of the global financial crisis, conventional finance in general and conventional mutual funds in particular, are facing a plethora of recommendations for tighter control in terms of leverage and risk. By contrast, certain types of funds such as socially responsible investment (SRI) or Islamic funds have demonstrated greater stability in the unsettled global

\footnotetext{
is We are grateful to two anonymous referees and the guest editors for their comments which have contributed to improve the overall quality of the article. Juan Carlos Matallín-Sáez, Diego Víctor de Mingo-López and Emili Tortosa-Ausina acknowledge the financial support provided by the Ministerio de Economía y Competitividad (ECO2014-55221-P), Universitat Jaume I (P1 1B2012-07 and P1 1B2014-17) and Generalitat Valenciana (PROMETEOII/2014/046). The usual disclaimer applies.

* Corresponding author at: Departament d'Economia, Universitat Jaume I, Campus del Riu Sec, 12071 Castelló de la Plana, Spain.

E-mail address: tortosa@uji.es (E. Tortosa-Ausina).
} 
financial markets (Askari et al., 2010). In the case of Islamic finance, ${ }^{1}$ some of the most recent statistics place Islamic finance assets above the $\$ 1$ trillion mark, with around 350 institutions competing to cater for the needs of both Muslim and Western investors.

While it is natural to expect an expansion of Islamic finance in Muslim dominated countries as both population and per capita income increase, it is more surprising to observe the rising appeal to non-Muslims, many of whom have been driven to look for new options by the unattractive risk/return mix of conventional products. Islamic finance has become an important issue for financial markets worldwide, as witnessed by the large expansion of Islamic equity indices, Sukuk indices and Islamic mutual funds, in many occasions under the auspices of Western governments.

Islamic mutual funds offer a diversified income source by investing pooled funds in assets that appreciate over time. In contrast to conventional mutual funds, Islamic fund investments are restricted by Shari'ah (Islamic Law) principles, which prohibit interest payments, investing in complex derivatives (e.g., conventional credit default swaps, futures or options) and short-selling. In addition, business and financial screening ensures that funds are not directed to companies that are either heavily indebted to or engaged in non-permissible lines of business (e.g., gambling, conventional finance, weapons). For an in-depth discussion on business type and financial screening, see Ali (2005), Elfakhani et al. (2007) and Khatkhatay and Nisar (2007), among others. Nevertheless, both Islamic and conventional funds are actively managed in the sense that fund managers re-balance portfolios in order to attain the funds' objectives, although these objectives may differ substantially according to which type of fund it is. For example, rather than pursuing the maximum possible return, an Islamic mutual fund may settle for a diversification strategy while minimizing potential losses or not investing in entities that do not meet the screening criteria.

Much scholarly attention has recently turned to analyzing the performance of faith-based and ethically oriented funds such as Islamic funds and SRI funds. Abdelsalam et al. (2014b) point out that the two types of funds have strict financial and social criteria for evaluating investments to ensure that the securities selected are consistent with their value system and beliefs. However, they also highlight that the differences lie mainly in the asset allocation stage. Erragraguy and Revelli (2015) state that SRIs apply a set of stock screening methods based on environmental, social and corporate governance (ESG) criteria, often engaging with local communities and active shareholders who encourage appropriate corporate strategies. An Islamic investment policy, however, conforms entirely to the Shari'ah principles. Abdelsalam et al. (2014b) explain that SRI mutual funds can freely choose between debt-bearing investments and equity-bearing investments, as long as the stocks selected strictly adhere to social, moral or environmental beliefs. The same authors state that, Islamic funds, in contrast, undergo a more rigorous screening process to select portfolios that meet both the qualitative and quantitative criteria established by Shari'ah principles. This entails excluding companies engaged in activities prohibited under Shariah; companies whose capital structures rely heavily on debt financing in order to avoid dealing with interest; and all investments in fixed income instruments, such as corporate bonds, certificates of deposit (CDs), preferred stocks, warrants and some derivatives (Williams and Zinkin, 2010). Shari'ah also provides structural guidance on the governance and management structure of Islamic mutual funds. Hence, Islamic mutual funds appear to have a wider scope of investment in ethical and socially responsible mutual funds. SRI mutual funds offer the closest alternative for a comparative evaluation of Islamic mutual fund performance. It is worth mentioning in the context of this study that MENA countries do not have SRI funds as Islamic funds are considered the ethically/religiously oriented option in the region.

Although the influence of Islamic finance is spreading internationally, its relevance and relative importance varies across countries. Its role in Western economies is relatively modest compared to other types of investment (such as SRI), whereas it is much more firmly established in other areas such as the Middle East and North Africa (MENA) region, specifically, the countries in this region that are members of the Gulf Cooperation Council (GCC).

Academic interest in the MENA region has increased for a variety of reasons that go beyond finance or economics. Several countries in the region have recently experienced political turmoil which, in some cases (such as Egypt), is not entirely over. Accordingly, various contributions have examined the general socioeconomic and political aspects related to the Arab Spring (Chaney et al., 2012; Winckler, 2013; Sekkat, 2014), and in some cases these analyses have emphasized the economic aspects. Examples of this can be found in Malik and Awadallah (2013), Knutsen (2014), and Chaney (2013).

In terms of economics and finance, although this region has always been regarded as having bank-based economies (Graham et al., 2013), its stock markets have grown in importance over the last two decades. This is because most countries in the region began to liberalize their stock markets in the 1990s-far later than comparative regions such as Latin America and Asia. Authors such as Naceur et al. (2008), Achy (2001), Neaime (2005) and Gentzoglanis (2007), among others, have analyzed various aspects of stock market liberalization in the MENA region, particularly aspects related to macroeconomic factors.

\footnotetext{
${ }^{1}$ Islamic finance is based upon the principle of risk sharing and avoidance of undue risk. Islamic financial products are mainly asset-backed and grounded on the risk-sharing principle on both the asset and the liability side of the balance sheet. Islamic financial products may be classified as equity-based or fee-based. A widely used equity-based contract is that of Mudarabah; this is an agreement between a financier and an entrepreneur to jointly enter a business venture. The financier provides capital whereas the entrepreneur provides the knowhow. Any profits are shared between the two parties at a pre-agreed ratio, while financial losses are borne by the financier in full. With Murabahah, an intermediary purchases an asset on the buyer's behalf and subsequently sells it to the buyer at a pre-agreed profit margin. For more detailed explanations of Islamic finance contracts, see Olson and Zoubi (2008), Khan (2010) and Khaldi and Hamdouni (2011).
} 
In addition to the liberalization of the stock markets, a subset of countries in the region has recently gained economic visibility. Specifically, the Gulf Cooperation Council (GCC) countries have had increased international exposure due to the surges in oil prices since the 1970s, the accumulation of petrodollars, and the global investments of their sovereign wealth funds (Graham et al., 2013). These and related issues have contributed to the steady growth of the GCC stock market during the last decade and, although total GCC market capitalization is well below $2 \%$ of world market capitalization, it constitutes roughly 70\% of total Arab stock market capitalization (Akoum et al., 2012; Graham et al., 2013). Despite the (growing) political, economic and financial interest in the region, and the increasing attention devoted to it by academics, policymakers and practitioners, some issues such as analyzing the performance of mutual funds investing in MENA countries are almost entirely non-existent.

Therefore, the first objective of our study is to compare the performance of conventional and Islamic funds in a region where most Islamic funds are concentrated. We estimate mutual fund performance using a methodology that considers factors related to the geographic area in which these funds invest. We do this in an attempt to avoid the presence of any bias introduced by omitting relevant benchmarks, as described by Pástor and Stambaugh (2002) and Matallín-Sáez (2006), among others. We propose a linear multifactor model in accordance with previous studies such as Sharpe (1992) and Elton et al. (1993a), among others, who also adjust mutual fund returns to a set of relevant benchmarks.

The second objective of the study is to compare the performance of funds in both (financial) crisis and recovery times. In the aftermath of the recent financial crisis, this issue has attracted great interest among analysts of conventional mutual funds. Kosowski (2011) and Glode (2011) find that funds, in general, perform better in bad economic times than in good ones. De Souza and Lynch (2012) also analyze this issue, finding a more complex picture to explain how performance can vary over the business cycle. Kacperczyk et al. (2014) also show that managers' skills are related to economic cycles. In line with this literature, we will also compare the performance of Islamic and conventional funds in periods of crisis and recovery. ${ }^{2}$ As far as we know, there is no previous evidence comparing this issue for Islamic and conventional funds in the MENA region investment area. We consider that this issue deserves investigation, given the intrinsic characteristics of this investment area, especially due to the constraints affecting Islamic funds.

In this regard, the available empirical evidence to date suggests that there are stock selection benefits to be found in small and specialized funds, which could lead to better performance than the market. Such funds may be created by applying stock selection criteria under the umbrella term of socially responsible investments (SRI) ${ }^{3}$ but may be further decomposed into ethical, social and religious investments. The rise of Islamic mutual funds has prompted interest in their financial performance and how they fare in comparison to conventional investments shown by several indicators. Restrictions such as those applied in Islamic finance would seem to make good investment sense, enhancing portfolio stability (Askari et al., 2010) particularly during financial downturns, whilst simultaneously offering comparable or even better returns to investors. This contention is supported by, for example, Merdad et al. (2010) study, which uses a sample of monthly data of Islamic and conventional funds in Saudi Arabia during the January 2003 to January 2010 period in order to examine risk return behavior. These authors use asset pricing models and take into account bearish and bullish periods, finding that Islamic funds underperform conventional funds in bull periods but outperform them in bear periods; thus they offer hedging opportunities to investors during economic downturns. Abdullah et al. (2007) draw a similar conclusion for the Malaysian capital market from January 1992 to December 2001 using a similar approach. Other studies such as Elfakhani et al. (2007) and Hayat and Kraeussl (2011), however, fail to find any statistical difference between the financial performance of Islamic and conventional funds. Yet, when the observation period considers bear and bull markets, results show that Islamic mutual funds significantly outperform their benchmarks; hence they appear as attractive choices in enhancing portfolio diversification due to their low correlation to the market. Accounting for this issue in the context of MENA emerging markets is yet to receive due attention, which motivates our second objective.

Finally, our study explores the determinants of mutual fund performance in the MENA region. To do this we apply a technique that is robust to deviations from normality in the data, and also reveals whether effects on performance vary for each

\footnotetext{
${ }^{2}$ Since the start of the 2008 global financial crisis, international financial markets have become more turbulent, and no country, whether developing or developed, was expected to escape its impact. Neaime (2012) argues that the spillover effects of the recent global financial crisis on MENA stock markets varied according to their degree of financial integration with the more mature financial markets. Among the non-oil producing MENA countries, Morocco experienced a milder stock market capitalization decline from US\$75.5 billion in 2007 to US\$62.9 in 2009. Tunisia, on the other hand, saw its market capitalization improve from US\$5.3 billion in 2007 to US\$9.1 billion in 2009. The effect on oil producing MENA countries also differed according to the degree of their integration with global markets. UAE saw its market capitalization fall by almost half from US\$224.6 billion in 2007 , to US\$109.6 billion in 2009. Similarly, in Kuwait stock market capitalization fell from US $\$ 188$ billion in 2007 to US $\$ 95.9$ billion in 2009. However, the decline in the capitalization of the region's largest stock market, Saudi Arabia, was less abrupt during this period, falling from US\$515 billion in 2007 , to US\$318 billion in 2009 mainly because its market has remained relatively closed to foreign investors. The stock market capitalizations in Egypt and Jordan declined sharply between 2007 and 2009 as a result of the global financial crisis, from US $\$ 139.3$ and US $\$ 41.3$ billion in 2007, to US\$89.95 and US\$31.86 billion in 2009 , respectively. In general and as the crisis began to unfold, it was noted that the global financial crisis had a less dramatic effect on the MENA region than on similar emerging markets or transition economies such as South and East Asia, Latin America, and the Caribbean, where the fallout from the global crisis was devastating, in some instances three times that of MENA countries, which weathered the storm better primarily because of relatively lower financial and economic integration with global markets.

3 The main differences between Islamic finance and the rest of SRI are: (i) the screening rules are based on Shari'ah and the investment has to be approved by a Shari'ah supervisory board appointed by the fund management; (ii) the extensive use of financial screening criteria; (iii) the provision for zakat (Islamic religious tax), a charitable donation made at the fund level to "purify" any earnings from non-permissible sources. Most recently, the Securities Commission in Malaysia made a move toward harmonization by adopting the financial criteria used by major index providers.
} 
tail of the distribution. We evaluate the effect of a diverse set of covariates on fund performance, including variables related to specific fund characteristics (size, age, costs and survivorship bias) as well as other variables related to the environment, in order to evaluate the challenges funds face when investing in a region with a certain political instability. This analysis is also split into Islamic and conventional mutual funds.

The remainder of the paper is structured as follows. Section 2 provides details on the methodologies used to measure funds' performance. Section 3 describes the data used in the study. Section 4 reports the results, and Section 5 closes with some concluding remarks.

\section{Methodology: mutual fund performance measurement}

We now present the methods and models used to measure the performance of conventional and Islamic funds. Previous mutual fund performance literature has extensively applied linear models, which adjust a fund's returns to different risk factors. Notable contributions to this literature include Fama and French (1993) and Carhart (1997). Fama and French (1993) use three factors in their model to explain mutual fund returns based on, (i) the return of the market, (ii) the return on the size (SMB, small minus big) and (iii) the return on the book-to-market (HML, high minus low) factor mimicking portfolios. Carhart (1997) extends the Fama and French (1993) three-factor model by adding the momentum factor (UMD, up minus down). Other performance evaluation models (Daniel et al., 1997) consider portfolio holdings data and characteristic-based benchmarks.

Further studies (Sharpe, 1992; Elton et al., 1993a) consider linear models including as factors the returns of the benchmarks represented by the asset classes in which the evaluated funds invest. In line with these studies, given that our interest lies in evaluating the performance of funds with differing geographic investment focuses, we propose a linear model with multiple benchmarks as follows:

$$
r_{p, t}=\alpha_{p}+\beta_{p, g} r_{g, t}+\beta_{p, m} r_{m, t}+\varepsilon_{p, t}
$$

In this expression $r_{p, t}$ corresponds to the excess return over the risk-free asset of the assessed fund, and $\alpha_{p}$ measures the fund's abnormal performance. The risk factors correspond to the excess returns, which are: (i) a global benchmark representing investment in different markets in the fund's geographic area of influence $\left(r_{g, t}\right)$; (ii) a specific benchmark representing investment conditioned by the geographic focus defined by the fund $\left(r_{m, t}\right)$. Due to the disparate behavior of the investment areas under study, we consider a specific benchmark in order to avoid bias caused by omitting relevant benchmarks, as pointed out by Pástor and Stambaugh (2002) and Matallín-Sáez (2006), among others.

To test the robustness of these results, we use two further fund performance measures. The first is the three-factor model described in Fama and French (1993), which considers the size and the book-to-market ratio in addition to the market factor when evaluating the mutual fund performance, plus a global benchmark, $r_{g, t}$, to consider different geographic areas of the fund's influence. The second combines the factors of the previous model with the momentum factor described in Carhart (1997). These models are shown in Eqs. (2) and (3), respectively.

$$
\begin{aligned}
& r_{p, t}=\alpha_{p}+\beta_{p, g} r_{g, t}+\beta_{p, m} r_{m, t}+\beta_{p, S M B} S M B_{t}+\beta_{p, H M L} H M L_{t}+\varepsilon_{p, t} \\
& r_{p, t}=\alpha_{p}+\beta_{p, g} r_{g, t}+\beta_{p, m} r_{m, t}+\beta_{p, S M B} S M B_{t}+\beta_{p, H M L} H M L_{t}+\beta_{p, U M D} U M D_{t}+\varepsilon_{p, t}
\end{aligned}
$$

where $S M B_{t}, H M L_{t}$ and $U M D_{t}$ are the monthly returns on the size, book-to-market, and momentum factor mimicking portfolios, respectively.

\section{Data}

We use monthly data on Islamic and conventional equity funds over the period of January 2006 to December 2013 in the MENA region. ${ }^{4}$ Our sample includes funds that invest in Egypt, Kuwait, Morocco, Oman, Qatar, Saudi Arabia, Tunisia, Turkey, United Arab Emirates and other funds whose investment focus is not restricted to a particular country but referred to either the GCC or MENA general investment zones. As noted in the introduction, our focus on the MENA region is driven, in part, by the importance of Islamic finance in the region, particularly in the GCC countries. The sample is free of survivorship bias and consists of 336 mutual funds, 105 of which are Islamic and 231, conventional. For mutual funds, benchmarks and factors, returns are computed monthly. ${ }^{5}$

Since the period analyzed includes the regional political crisis, it could be subject to potential regime shifts. Dungey and Zhumabekova (2001) have shown in a different but related setting (tests of contagion effects) that such regime shifts could have a considerable impact on our results, due to the differing lengths of the "crisis" and "non-crisis" periods. Other contributions have considered the potential effects of regime shifts, including Guo et al. (2011), Longstaff (2010), Kenourgios

\footnotetext{
4 The sample period was partly chosen because when more years were included, there was a substantial decline in the number of funds available for the study, since we considered funds for which information for at least one year was available. We also considered 2006 was a reasonable starting point as the year prior to the financial crisis. We refer to $2006 / 1-2009 / 2$ as the "crisis period" because of its high volatility, and the period from $2009 / 3$ to $2013 / 12$ as the "recovery period", due to its moderate stock market growth and low volatility.

5 Islamic investment differs from conventional investment mainly due to tighter constraints on the former. Notwithstanding the restrictions of Islamic
} 
Table 1

Data on the geographical zone and benchmarks used.

\begin{tabular}{llll}
\hline Geographical investment focus & Number of funds & Benchmarks & Specific \\
\cline { 3 - 4 } & & General & MSCI Egypt \\
\hline Egypt & 2 & S\&P Pan Arab Composite & MSCI Kuwait \\
GCC $^{a}$ & 44 & S\&P GCC Composite & MSCI Morocco \\
Kuwait & 41 & S\&P GCC Composite & MSCI Oman Arab Composite \\
MENA & 12 & S\&P Pan Arab Composite & MSCI Qatar \\
Morocco & 84 & S\&P GCC Composite & MSCI Saudi Arabia Domestic GR USD \\
Oman & 4 & S\&P GCC Composite & MSCI Tunisia \\
Qatar & 9 & S\&P GCC Composite & MSCI Turkey \\
Saudi Arabia & 71 & S\&P Pan Arab Composite & MSCI United Arab Emirates \\
Tunisia & 16 & S\&P Pan Arab Composite & \\
Turkey & 41 & S\&P GCC Composite & \\
United Arab Emirates & 12 & &
\end{tabular}

a GCC and MENA refer to those funds whose general investment zones are either GCC or MENA countries, but there is no specific information on the country where the investment takes place.

Table 2

Descriptive statistics for the sample of funds ( $t$-statistics in parentheses).

\begin{tabular}{llll}
\hline Geographical investment focus & Number of funds & Average return (annualized, \%) $^{\mathrm{a}}$ & Average standard deviation (annualized, \% $^{\mathrm{a}}$ \\
\hline Egypt & 2 & $-12.50(-7.350)$ & $18.51(3.514)$ \\
GCC $^{\mathrm{b}}$ & 44 & $2.12(1.584)$ & $19.33(15.009)$ \\
Kuwait & 41 & $-6.68(-6.361)$ & $21.97(27.435)$ \\
MENA $^{\mathrm{b}}$ & 12 & $-1.00(-0.229)$ & $19.23(4.982)$ \\
Morocco & 84 & $6.76(8.925)$ & $17.33(26.577)$ \\
Oman & 4 & $4.07(2.485)$ & $15.68(4.409)$ \\
Qatar & 9 & $7.71(6.194)$ & $20.27(8.036)$ \\
Saudi Arabia & 71 & $3.84(3.598)$ & $22.39(20.049)$ \\
Tunisia & 16 & $-6.19(-3.431)$ & $10.79(18.654)$ \\
Turkey & 41 & $5.02(5.022)$ & $32.84(32.218)$ \\
United Arab Emirates & 12 & $8.02(1.800)$ & $26.19(14.462)$ \\
Total & 336 & $2.71(5.229)$ & $21.26(42.992)$ \\
\hline
\end{tabular}

a The values in this table have been annualized from monthly frequency data.

b GCC and MENA refer to those funds whose general investment zones are either GCC or MENA countries, but there is no specific information on the country where the investment takes place.

et al. (2011) and Aloui et al. (2011), among others. In order to control for these potential effects, we split the period of analysis in two subperiods, one in which the effects of the crisis were stronger and the other, the recovery period.

The descriptive statistics in Tables $1-5$ report information on the number of funds and their average return and standard deviation for the countries and geographic areas included in the analysis, and also the benchmarks used. Table 1 reports information on the benchmarks considered for the funds with a given geographic investment focus (both general and specific); Tables 2 and 3 report average return and average standard deviation for the sample of funds and benchmarks used, respectively; and Table 4 reports the correlations between benchmarks.

More specifically, Table 1 reports information on these investment areas as well as the number of funds and benchmarks (both general and specific) used in Model (1). The table shows the clear differences in the number of funds by area and country, ranging from Morocco (84), Saudi Arabia (71) and GCC (44) at the top end, and Qatar (9), Oman (4) and Egypt (2) which have far fewer funds.

The descriptive statistics reported in these tables reveal considerable disparities in average return (Table 2). For the 336 funds in the sample, the average return is positive at $2.71 \%$. However, negative average returns are reported for funds investing in Egypt (-12.50\%), in contrast to much better returns (8.02\%) for those investing in United Arab Emirates. While

finance, entrepreneurial risk and profit from it are permitted. Investing in mutual funds is therefore allowed, provided that they adhere to the five main Islamic finance principles. Since the principle of not receiving or visser2013islamic, the criteria set by the Dow Jones Shari'ah Supervisory Board seem to be the standard in the investment industry. Under these standards, firms must adhere to the following financial criteria in order to be classified as halal (permissible according to Islamic law):

- total debt divided by the trailing 12 -month average market capitalization must be less than $33 \%$;

- cash plus interest-bearing securities divided by the trailing 12-month average market capitalization must be less than 33\%; and

- accounts receivable divided by the 12 -month average market capitalization must be less than $33 \%$.

Islamic equity funds were almost non-existent before the 1990s, since when they have attracted considerable interest, particularly among Muslim investors, in parallel with increased wealth in the Middle East (Hayat and Kraeussl, 2011). 
Table 3

Descriptive statistics for benchmarks and factors.

\begin{tabular}{|c|c|c|c|c|c|c|c|c|}
\hline \multirow[t]{2}{*}{ Geographical investment focus } & \multicolumn{4}{|c|}{ Average return (annualized, \%) ${ }^{\mathrm{a}}$} & \multicolumn{4}{|c|}{ Average standard deviation (annualized, \%) } \\
\hline & All sample & Crisis & Recovery & $\begin{array}{l}\text { Difference } \\
\text { (recovery-crisis) }\end{array}$ & All sample & Crisis & Recovery & $\begin{array}{l}\text { Difference } \\
\text { (recovery-crisis) }\end{array}$ \\
\hline Risk free asset & 1.39 & 3.43 & 0.06 & -3.37 & 0.57 & 0.50 & 0.02 & -0.48 \\
\hline Egypt & 8.23 & -4.42 & 16.52 & 20.95 & 34.97 & 37.86 & 32.71 & -5.15 \\
\hline $\mathrm{GCC}^{\mathrm{b}}$ & -1.40 & -30.26 & 17.51 & 47.76 & 22.68 & 28.61 & 15.48 & -13.12 \\
\hline Kuwait & 0.94 & -15.89 & 11.97 & 27.87 & 24.71 & 28.15 & 21.58 & -6.57 \\
\hline MENA $^{\mathrm{b}}$ & -1.15 & -26.03 & 15.15 & 41.18 & 21.04 & 26.82 & 14.32 & -12.50 \\
\hline Morocco & 9.27 & 27.40 & -2.61 & -30.01 & 21.99 & 27.77 & 16.29 & -11.48 \\
\hline Oman & 3.70 & -7.78 & 11.22 & 19.00 & 21.38 & 27.64 & 15.62 & -12.02 \\
\hline Qatar & 7.45 & -17.67 & 23.90 & 41.57 & 28.32 & 38.41 & 17.45 & -20.96 \\
\hline Saudi Arabia & 0.05 & -32.54 & 21.40 & 53.94 & 29.18 & 38.75 & 18.16 & -20.59 \\
\hline Tunisia & 8.87 & 12.26 & 6.65 & -5.61 & 18.86 & 19.04 & 18.71 & -0.33 \\
\hline Turkey & 9.65 & -11.14 & 23.27 & 34.41 & 39.81 & 45.74 & 34.84 & -10.90 \\
\hline United Arab Emirates & -1.47 & -47.26 & 28.53 & 75.79 & 35.06 & 38.60 & 29.48 & -9.11 \\
\hline
\end{tabular}

a The values in this table have been annualized from monthly frequency data.

b GCC and MENA refer to those funds whose general investment zones are either GCC or MENA countries, but there is no specific information on the country where the investment takes place.

Table 4

Correlation matrix among benchmarks ( $t$-statistics in parentheses).

\begin{tabular}{|c|c|c|c|c|c|c|c|c|c|c|c|}
\hline & Egypt & $\mathrm{GCC}^{\mathrm{a}}$ & Kuwait & MENA $^{a}$ & Morocco & Oman & Qatar & Saudi Arabia & Tunisia & Turkey & UAE \\
\hline Egypt & 1.000 & & & & & & & & & & \\
\hline $\mathrm{GCC}^{\mathrm{a}}$ & $\begin{array}{l}0.556 \\
(6.479)\end{array}$ & 1.000 & & & & & & & & & \\
\hline Kuwait & $\begin{array}{l}0.371 \\
(3.874)\end{array}$ & $\begin{array}{l}0.564 \\
(6.630)\end{array}$ & 1.000 & & & & & & & & \\
\hline MENA $^{a}$ & $\begin{array}{l}0.633 \\
(7.934)\end{array}$ & $\begin{array}{l}0.991 \\
(73.320)\end{array}$ & $\begin{array}{l}0.569 \\
(6.707)\end{array}$ & 1.000 & & & & & & & \\
\hline Morocco & $\begin{array}{l}0.458 \\
(4.998)\end{array}$ & $\begin{array}{l}0.237 \\
(2.366)\end{array}$ & $\begin{array}{l}0.315 \\
(3.217)\end{array}$ & $\begin{array}{l}0.316 \\
(3.232)\end{array}$ & 1.000 & & & & & & \\
\hline Oman & $\begin{array}{l}0.484 \\
(5.355)\end{array}$ & $\begin{array}{l}0.683 \\
(9.068)\end{array}$ & $\begin{array}{l}0.568 \\
(6.691)\end{array}$ & $\begin{array}{l}0.699 \\
(9.488)\end{array}$ & $\begin{array}{l}0.250 \\
(2.502)\end{array}$ & 1.000 & & & & & \\
\hline Qatar & $\begin{array}{l}0.528 \\
(6.030)\end{array}$ & $\begin{array}{l}0.682 \\
(9.033)\end{array}$ & $\begin{array}{l}0.491 \\
(5.468)\end{array}$ & $\begin{array}{l}0.701 \\
(9.542)\end{array}$ & $\begin{array}{l}0.163 \\
(1.605)\end{array}$ & $\begin{array}{l}0.608 \\
(7.421)\end{array}$ & 1.000 & & & & \\
\hline Saudi Arabia & $\begin{array}{l}0.451 \\
(4.903)\end{array}$ & $\begin{array}{l}0.927 \\
(23.981)\end{array}$ & $\begin{array}{l}0.312 \\
(3.180)\end{array}$ & $\begin{array}{l}0.910 \\
(21.298)\end{array}$ & $\begin{array}{l}0.124 \\
(1.216)\end{array}$ & $\begin{array}{l}0.515 \\
(5.823)\end{array}$ & $\begin{array}{l}0.523 \\
(5.951)\end{array}$ & 1.000 & & & \\
\hline Tunisia & $\begin{array}{l}0.328 \\
(3.364)\end{array}$ & $\begin{array}{l}0,243 \\
(2.429)\end{array}$ & $\begin{array}{l}0.163 \\
(1.598)\end{array}$ & $\begin{array}{l}0.266 \\
(2.677)\end{array}$ & $\begin{array}{l}0.295 \\
(2.999)\end{array}$ & $\begin{array}{l}0.358 \\
(3.718)\end{array}$ & $\begin{array}{l}0.186 \\
(1.838)\end{array}$ & $\begin{array}{l}0.150 \\
(1.467)\end{array}$ & 1.000 & & \\
\hline Turkey & $\begin{array}{l}0.603 \\
(7.337)\end{array}$ & $\begin{array}{l}0.516 \\
(5.835)\end{array}$ & $\begin{array}{l}0.393 \\
(4.144)\end{array}$ & $\begin{array}{l}0.542 \\
(6.254)\end{array}$ & $\begin{array}{l}0.306 \\
(3.121)\end{array}$ & $\begin{array}{l}0.418 \\
(4.465)\end{array}$ & $\begin{array}{l}0.482 \\
(5.333)\end{array}$ & $\begin{array}{l}0.420 \\
(4.482)\end{array}$ & $\begin{array}{l}0.318 \\
(3.253)\end{array}$ & 1.000 & \\
\hline UAE & $\begin{array}{l}0.543 \\
(6.266)\end{array}$ & $\begin{array}{l}0.743 \\
(10.757)\end{array}$ & $\begin{array}{l}0.492 \\
(5.485)\end{array}$ & $\begin{array}{l}0.755 \\
(11.151)\end{array}$ & $\begin{array}{l}0.206 \\
(2.043)\end{array}$ & $\begin{array}{l}0.642 \\
(8.120)\end{array}$ & $\begin{array}{l}0.668 \\
(8.701)\end{array}$ & $\begin{array}{l}0.558 \\
(6.515)\end{array}$ & $\begin{array}{l}0.288 \\
(2.912)\end{array}$ & $\begin{array}{l}0.518 \\
(5.865)\end{array}$ & 1.000 \\
\hline
\end{tabular}

a GCC and MENA refer to those funds whose general investment zones are either GCC or MENA countries, but there is no specific information on the country where the investment takes place.

only two funds invest in Egypt, this poor performance was also found for funds investing in Kuwait (-6.68\%). Although this hypothesis merits further careful examination, the funds with the worst average return correspond to those investing in countries where intense political uprisings took place (Egypt and Tunisia, $-6.19 \%$ ).

Table 3 shows some descriptive statistics for market factors used when measuring fund performance. These data reveal higher average returns in non-GCC country investment areas (Egypt, Morocco, Tunisia and Turkey) than in the other areas. This result, together with the disparities found for risk and returns, alerts us to the need to consider specific market factors in order to adjust mutual fund returns. If we proceed otherwise, for instance, by considering only one overall market factor, performance would be affected by a local bias indicating that the best (worst) funds are those corresponding to the best (worst) investment areas.

Finally, Table 5 reports information on the two summary statistics, average and standard deviation, by grouping mutual funds according to different criteria. Information in the upper panel correspond to those funds investing in GCC or MENA (excluding GCC) general investment zones and, on average, the funds investing in the MENA region (excluding GCC) show higher returns. The lower panels separate funds according to their Islamic orientation, and returns differ depending on the investment zone. This analysis becomes deeper and more interesting when mutual fund performance is measured, and is dealt with in the next section. Table 5 also reports the Jarque-Bera statistic for normal distribution of the sample. This statistic reaches high levels for all investment zones or Islamic orientation considered, which means that the returns are non-normally distributed. This result is not surprising, due to the wide differences between countries used in the model. 
Table 5

Descriptive statistics for the sample of funds and benchmarks used, groupings ( $t$-statistics in parentheses).

\begin{tabular}{|c|c|c|c|c|c|c|}
\hline \multirow[t]{2}{*}{ Geographical investment focus } & \multirow{2}{*}{$\begin{array}{l}\text { Number of } \\
\text { funds }\end{array}$} & \multirow{2}{*}{$\begin{array}{l}\text { Average return } \\
\text { (annualized) }^{\mathrm{a}}\end{array}$} & \multirow{2}{*}{$\begin{array}{l}\text { Average standard } \\
\text { deviation } \\
\text { (annualized) }^{\mathrm{a}}\end{array}$} & \multirow{2}{*}{$\begin{array}{l}\text { Jarque-Bera } \\
\text { statistic }\end{array}$} & \multicolumn{2}{|c|}{ Brown-Forsythe test } \\
\hline & & & & & F-statistic & $p$-value \\
\hline \multicolumn{7}{|c|}{ Grouping by general investment zone } \\
\hline GCC-group ${ }^{\mathrm{b}}$ & 181 & $1.52 \%(2.058)$ & $21.55 \%(35.337)$ & $139.15(3.702)$ & 4.780 & 0.000 \\
\hline MENA-excluding GCC ${ }^{c}$ & 155 & $4.11 \%(5.776)$ & $20.92 \%(26.068)$ & $253.30(2.233)$ & 13.286 & 0.000 \\
\hline Total & 336 & & & & & \\
\hline \multicolumn{7}{|l|}{ Grouping by Islamic orientation } \\
\hline Islamic & 105 & $2.11 \%(2.129)$ & $19.23 \%(23.147)$ & $117.15(2.333)$ & 5.059 & 0.000 \\
\hline Conventional & 231 & $2.99 \%(4.926)$ & $22.18 \%(36.746)$ & $225.16(2.872)$ & 9.622 & 0.000 \\
\hline Total & 336 & & & & & \\
\hline \multicolumn{7}{|c|}{ Grouping by Islamic orientation (only GCC general investment zone) } \\
\hline Islamic & 93 & $2.45 \%(2.309)$ & $19.94 \%(22.738)$ & $128.58(2.273)$ & 4.895 & 0.000 \\
\hline Conventional & 88 & $0.53 \%(0.522)$ & $23.25 \%(28.655)$ & $150.33(3.068)$ & 4.602 & 0.000 \\
\hline Total & 181 & & & & & \\
\hline
\end{tabular}

a The values in this table have been annualized from monthly frequency data.

b GCC-group refers to those funds investing in GCC countries.

${ }^{c}$ MENA-excluding GCC group refers to those funds investing in the MENA region, excluding GCC countries.

Because of this non-normality, and to check for heteroskedasticity in the data, we also run the Brown-Forsythe test; the statistic and its $p$-value are presented in the last columns of Table 5. Results of this test show that the group variances are significantly different for all confidence levels considered.

\section{Results}

\subsection{Results for the entire period}

Table 6 reports the results for the entire period of analysis (2006-2013) and all countries in the sample, together with the number of funds for each country or geographic area considered and their average performance $(\alpha)$ using different models over the analyzed period. Differences between alphas and their $t$-statistics are also reported to analyze whether these differences are statistically significant or not.

As in the data section, we report results according to investment zone ${ }^{6}$ (the two upper panels) and Islamic or conventional orientation (the two lower panels).

\subsection{Results based on summary statistics}

The information in the upper panel shows that, on average, the performance of the 336 funds in the sample is negative when considering Model (1) (-0.5770\%). However, for Models (2) and (3), overall mutual fund performance appears to be positive (1.1577\% and $1.0846 \%$, respectively), although these results are upwardly biased because results ${ }^{7}$ could not be obtained for some countries, notably Kuwait and Tunisia (alpha of $-6.4385 \%$ and $-5.2808 \%$ when considering Model (1), respectively).

The upper panel of Table 6 shows remarkable variations in mutual fund performance across countries. For instance, in the results of Model (1), similarly to findings in Section 3 for the returns, for funds investing in Egypt $(-10.4549 \%)$ average performance is negative, but it is much better (4.1586\%) for funds investing in Morocco. Whereas only two funds invest in Egypt, this poor performance was also seen for the 41 funds investing in Kuwait (-6.4385\%). Although this hypothesis merits further careful examination, with the exception of Kuwait, the funds with the worst average performance are those investing in countries where intense political uprising took place (Egypt and Tunisia, $-10.4549 \%$ and $-5.2808 \%$, respectively). For robustness purposes, we find no significant differences between Models (2) and (3) and Model (1) for any of the countries considered (last columns of Table 6). The differences in performance across countries persist when considering these models, and funds investing in Egypt (Morocco) continue to be, in general, the funds with the worst (best) performance.

\footnotetext{
${ }^{6}$ In the upper panel, apart from individual countries we also consider GCC and MENA categories since some funds invest in specific countries whereas others invest in more general areas (GCC and MENA) without specifying which particular country.

7 Unfortunately we were only able to obtain data of the market factors for Kuwait, Oman, Qatar, Saudi Arabia, and Tunisia and were therefore unable to run the Fama and French (1993) and Carhart (1997) extended models.
} 
Table 6

Results for mutual fund performance $(\alpha)$, whole period (2006-2013).

\begin{tabular}{|c|c|c|c|c|c|c|c|}
\hline $\begin{array}{l}\text { Number of } \\
\text { funds }\end{array}$ & Model (1) (\%) & Model (2) (\%) & Model (3) (\%) & $\begin{array}{l}\text { Difference } \\
\text { Model } \\
\text { (1)-Model (2) } \\
(\%)\end{array}$ & $p$-value & $\begin{array}{l}\text { Difference } \\
\text { Model } \\
\text { (1)-Model (3) } \\
\text { (\%) }\end{array}$ & $p$-value \\
\hline
\end{tabular}

\begin{tabular}{|c|c|c|c|c|c|c|c|c|}
\hline \multicolumn{9}{|c|}{ Grouping by geographical investment focus } \\
\hline Egypt & 2 & -10.4549 & -14.1543 & -12.5334 & 3.6994 & 0.5280 & 2.0785 & 0.7950 \\
\hline $\mathrm{GCC}^{\mathrm{a}}$ & 44 & -0.5877 & -0.8803 & -1.2830 & 0.2926 & 0.8510 & 0.6953 & 0.6720 \\
\hline Kuwait ${ }^{b}$ & 41 & -6.4385 & - & - & - & - & - & - \\
\hline MENA $^{a}$ & 12 & -3.2028 & -1.6785 & -1.0880 & -1.5244 & 0.7650 & -2.1148 & 0.6880 \\
\hline Morocco & 84 & 4.1586 & 4.3297 & 4.1487 & -0.1711 & 0.8320 & 0.0099 & 0.9900 \\
\hline Oman $^{\mathrm{b}}$ & 4 & 0.5276 & - & - & - & - & - & - \\
\hline Qatar ${ }^{\mathrm{b}}$ & 9 & 0.4174 & - & - & - & - & - & - \\
\hline Saudi Arabia ${ }^{b}$ & 71 & -0.7756 & - & - & - & - & - & - \\
\hline Tunisia $^{\mathrm{b}}$ & 16 & -5.2808 & - & - & - & - & - & - \\
\hline Turkey & 41 & -1.2405 & -1.1915 & -0.9882 & -0.0490 & 0.9540 & -0.2522 & 0.7630 \\
\hline United Arab Emirates & 12 & -0.7871 & -0.1593 & -0.1581 & -0.6279 & 0.7660 & -0.6290 & 0.7680 \\
\hline Total & 336 & -0.5770 & 1.1577 & 1.0846 & -1.7346 & 0.0050 & -1.6616 & 0.0080 \\
\hline \multicolumn{9}{|c|}{ Grouping by general investment zone } \\
\hline GCC-group ${ }^{c}$ & 181 & -1.9253 & -0.7258 & -1.0419 & -1.1995 & 0.2590 & -0.8834 & 0.4390 \\
\hline MENA-excluding GCC ${ }^{\mathrm{d}}$ & 155 & 0.9976 & 1.9165 & 1.9414 & -0.9189 & 0.2410 & -0.9438 & 0.2270 \\
\hline \multicolumn{9}{|c|}{ Grouping by Islamic orientation } \\
\hline Islamic & 105 & -1.3484 & -0.7038 & -0.7845 & -0.6446 & 0.6550 & -0.5639 & 0.7000 \\
\hline Conventional & 231 & -0.2263 & 1.6082 & 1.5370 & -1.8346 & 0.0070 & -1.7633 & 0.0110 \\
\hline \multicolumn{9}{|c|}{ Grouping by Islamic orientation (only GCC general investment zone) } \\
\hline Islamic & 93 & -1.3176 & -0.0759 & -0.4578 & -1.2417 & 0.4360 & -0.8599 & 0.5950 \\
\hline Conventional & 88 & -2.5676 & -1.3757 & -1.6261 & -1.1919 & 0.4010 & -0.9415 & 0.5640 \\
\hline
\end{tabular}

This table reports the results for the annualized mutual fund performance in the MENA region over the entire period (January 2006-December 2013). Performance is estimated by regressing monthly fund returns in excess of the risk-free asset using three models. Model (1) uses two explanatory variables: a global benchmark representing investment in different markets in the fund's geographic area of influence, and a specific benchmark representing investment conditioned by the geographical focus defined by the fund, both measured in excess of the risk-free asset. Models (2) and (3) are extensions of Model (1) based on the models of Fama and French (1993) and Carhart (1997). In each panel, the number of funds and their average performance are reported, grouped by their geographical investment focus, their general investment zone, or their Islamic orientation. The lower panel reports the results for the funds grouped by their Islamic orientation, but focusing only on funds with the GCC as the general investment zone. The differences between Models and corresponding $p$-values are also reported.

a GCC and MENA refer to those funds whose general investment zones are either GCC or MENA countries, but there is no specific information on the country where the investment takes place.

b Results for this country are only reported for Model (1) because of the lack of risk factor data.

c GCC-group refers to those funds investing in GCC countries.

d MENA-excluding GCC group refers to those funds investing in the MENA region, excluding GCC countries.

Table 6 shows the sample of 336 funds split into the 181 and 155 investing in GCC and MENA (excluding GCC) general investment zones, respectively. For Model (1) the difference in average performance is striking: negative ( $-1.9253 \%)$ for the GCC area and positive (0.9976\%) for the MENA (excluding GCC) area. With Models (2) and (3), mutual funds appear to perform better, but these results are upwardly biased for the same reasons as before, namely, not all the countries are considered. However, the differences in performance between the two areas of investment (GCC and MENA (excluding GCC) countries) remain when either model is considered (between 2.6423\% in Model (2) and 2.9833\% in Model (3)). Again, this outcome is generated by differing behaviors across countries.

The lower two panels in Table 6 report results according to fund orientation-Islamic or conventional. In the lower panel, the results are reported for funds investing in GCC countries only. We show the comparison of Islamic and conventional funds only for GCC because the vast majority of Islamic funds correspond to the GCC region. With Model (1), the average performance shows interesting trends since, regardless of the investment zone, conventional funds perform better than Islamic funds $(-0.2263 \%$ vs. $-1.3484 \%)$. However, if the analysis is confined to funds investing in GCC only, the opposite outcome is found: conventional funds show a much worse performance $(-2.5676 \%)$. Similar empirical evidence is found for Models (2) and (3).

\subsubsection{The shape of the distribution}

The results presented in the previous paragraphs are based on the analysis of average values. We complement this information by estimating nonparametrically, via kernel smoothing (see Silverman, 1986), the densities corresponding to the mutual funds according either to general investment region or to orientation. Fig. 1 shows the densities corresponding to the performance of Islamic and conventional funds, considering Model (1), depending on the general investment zone, i.e., MENA (excluding GCC), GCC or MENA. The vertical lines correspond to the mean for each group of funds (the solid line corresponds to the Islamic funds, and the dashed line to the conventional funds). 
(a) MENA (excl.GCC)

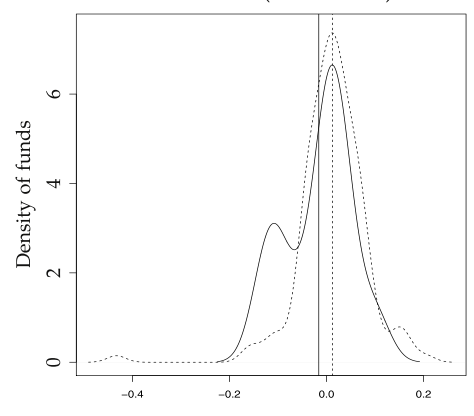

Islamic — Conventional ------

(Kolmogorov-Smirnov test $p$-value=0.4193) (b) GCC

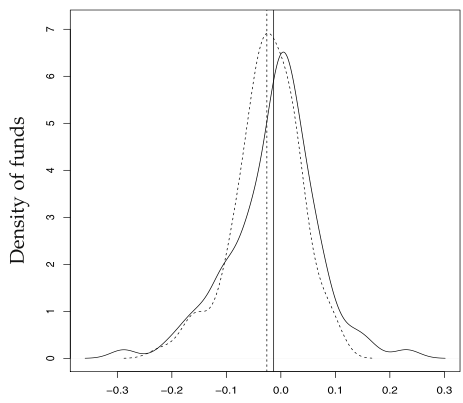

Islamic — Conventional ------ (c) MENA

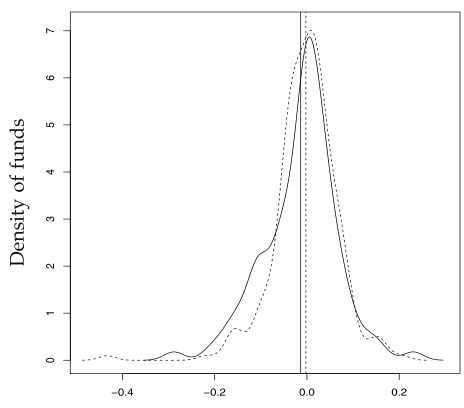

Islamic —- Conventional ------

(Kolmogorov-Smirnov test $p$-value $=0.2617$ )

Fig. 1. Performance $(\alpha)$, Islamic vs. conventional, whole period, Model (1).

(a) Islamic

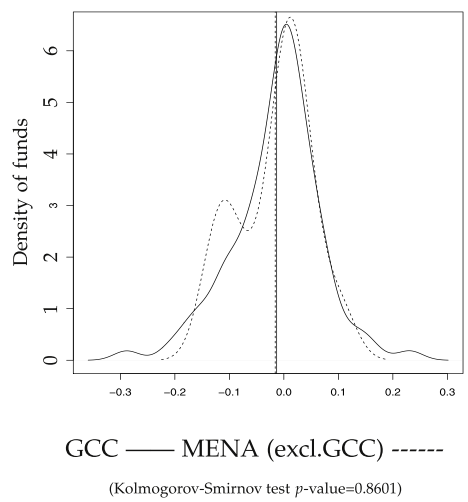

(b) Conventional

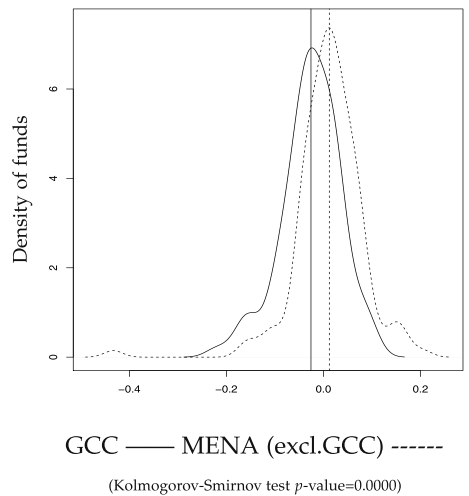

(c) All

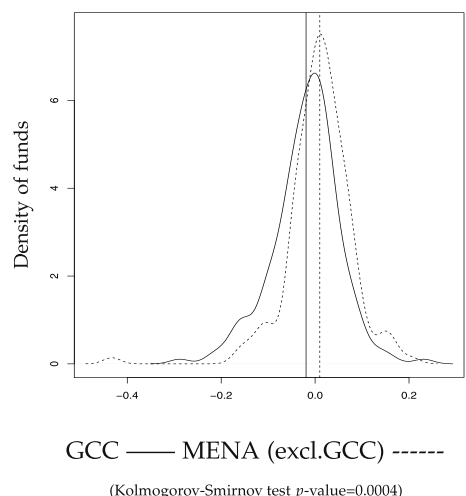

Fig. 2. Performance ( $\alpha$ ), GCC vs. MENA (excl.GCC), whole period.

Results show that there are differences, albeit quite small ones, and the figures nicely complement the analysis for the means. Fig. 1a indicates that the relatively lower average performance $(\alpha)$ of Islamic funds in MENA (excluding GCC) countries compared to their conventional counterparts is mainly caused by a group of relatively poorly performing countries-as shown by the notable bump in the vicinity of -0.15 . However, the majority of Islamic funds in the MENA countries (excluding GCC) perform quite similarly to their conventional counterparts, since both densities almost superimpose in the vicinity of the mean corresponding to the conventional funds-shown by the dashed vertical line. In contrast, there is a modest bump consisting of a small group of conventional funds (in the vicinity of 0.17 ) which perform particularly well. Focusing on the GCC region only (Fig. 1b), the emerging picture is different, as the density corresponding to Islamic funds (represented by the solid line) has shifted slightly rightwards-i.e., although the means do not differ much, a notable number of Islamic funds is performing better than their conventional counterparts. Taking the whole MENA region into account (Fig. 1c), the densities corresponding to Islamic and conventional funds almost overlap, indicating performance differences are negligible.

Fig. 2 reports similar information to Fig. 1, but sorted differently. In this case, the three subfigures display densities for Islamic, conventional and all funds-Fig. 2a-c, respectively. Compared to Fig. 1, the differences according to the region (GCC/MENA (excl.GCC)) are quite apparent, particularly for conventional funds in Fig. $2 \mathrm{~b}$.

From Figs. 1 and 2, and the analysis of means, we can conclude that for funds investing in these particular countries, the differences are relatively low (except for the best and worst funds, located at the tails of the distributions), and that context (i.e., GCC or MENA (excl.GCC) countries) is more important than the orientation (Islamic/conventional), as seen when Figs. 1c and $2 \mathrm{c}$ are compared directly.

We also report the densities for Models (2) and (3) (Figs. 3a through 6c), which basically corroborate the results for Model (1). However, the shape of the distributions is more similar when comparing Models (2) and (3) than when comparing either of them with Model (1), suggesting that the more sophisticated models yield more robust and consistent results.

\subsection{Results for crisis and recovery periods}

Within the period of analysis, the crisis period runs from the beginning of 2006 to February 2009 (2009/2), and the recovery period runs from March 2009 (2009/3) until December 2013 (2013/12). These periods were defined by analyzing 
(a) MENA (excl.GCC)

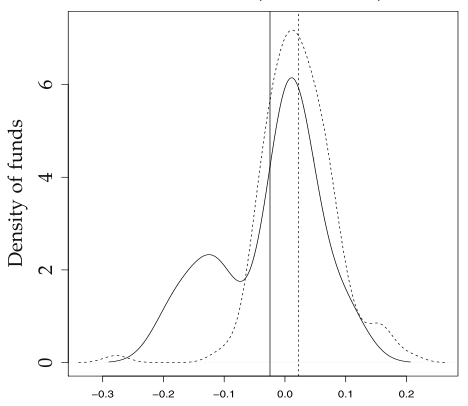

Islamic —- Conventional ------ (b) GCC

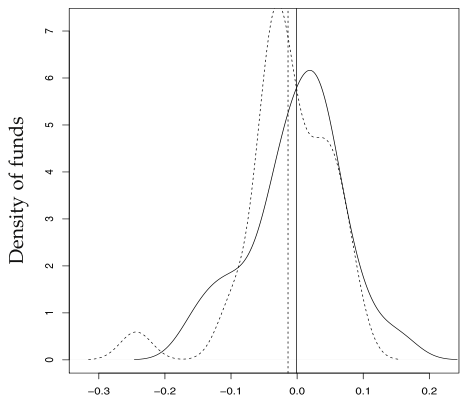

Islamic - Conventional (c) MENA

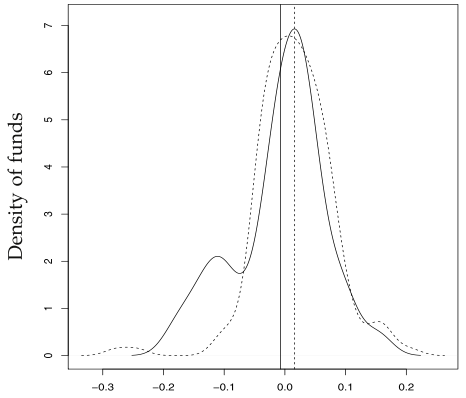

Islamic —- Conventional ------

Fig. 3. Performance $(\alpha)$, Islamic vs. conventional, whole period, Model (2).

(a) Islamic

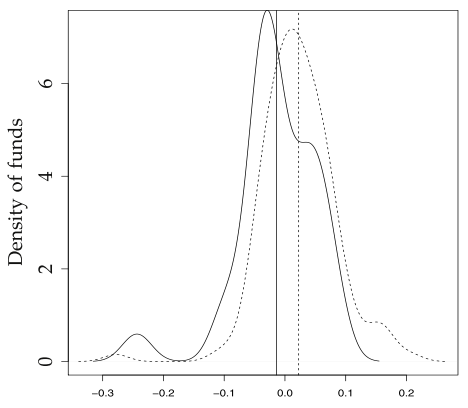

GCC — MENA (excl.GCC) ------ (b) Conventional

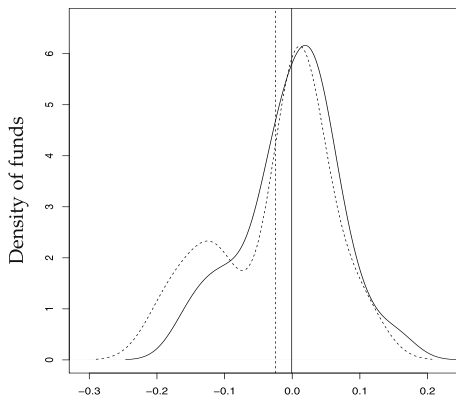

GCC — MENA (excl.GCC) ------ (c) All

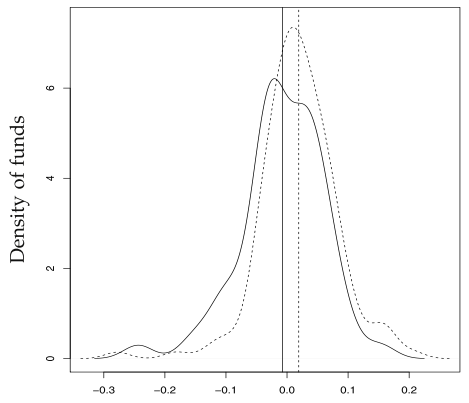

GCC — MENA (excl.GCC) ------

Fig. 4. Performance ( $\alpha$ ), GCC vs. MENA (excl.GCC), whole period, Model (2).

(a) MENA (excl.GCC)

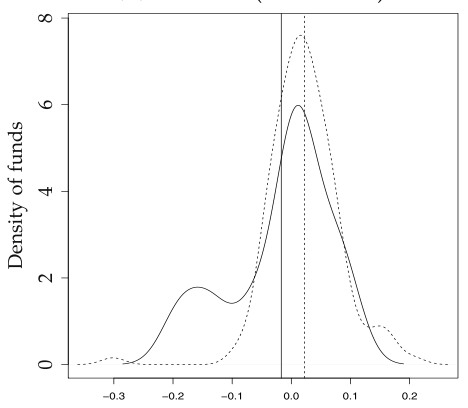

Islamic —- Conventional ------ (b) GCC

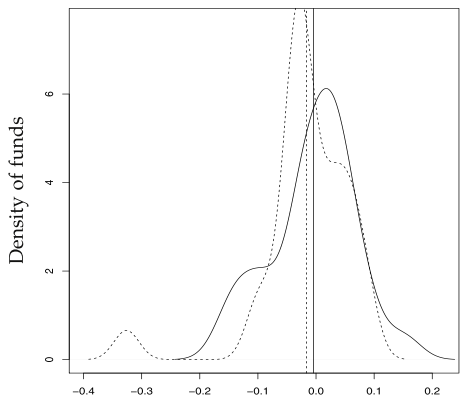

Islamic —- Conventional ------ (c) MENA

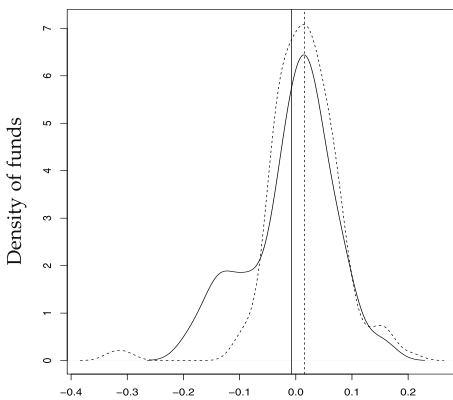

Islamic —— Conventional ------

Fig. 5. Performance $(\alpha)$, Islamic vs. conventional, whole period, Carhart (1997) model.

the evolution of the stock market indices for the GCC and MENA areas. In both cases, the lowest market values corresponded to February 2009. Table 3 shows that the first period is characterized by relatively high market volatility, and a bearish outcome, and the second by moderate stock market growth, with relatively low volatility. In this analysis, the number of funds is restricted to 200 to ensure the data corresponds to one year, both before and after the cutoff point (February 2009). As in the previous section, performance is estimated using Model (1). We compare the results for the performance and the systematic risk corresponding to the fund in both periods.

\subsubsection{Crisis period}

As in Table 6, Table 7 reports the results for performance estimation considering groups according to geographic investment focus, and Islamic or conventional orientation. A comparison of the results in Tables 6 and 7 reveals an overall improvement in performance. Hence, the upper panel of Table 7 shows how the average performance becomes positive (3.6623\%) with Model (1). If we consider Models (2) and (3), the overall performance also increases (7.0293\% and 6.6487\%), 
(a) Islamic

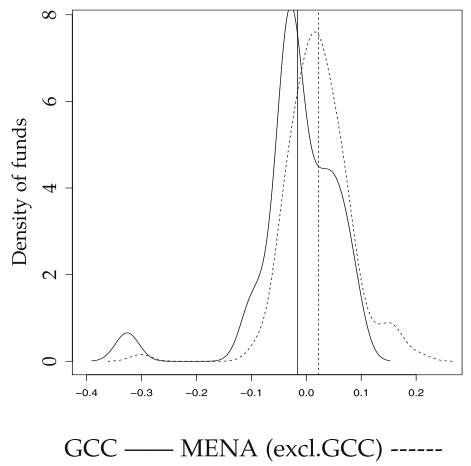

(b) Conventional

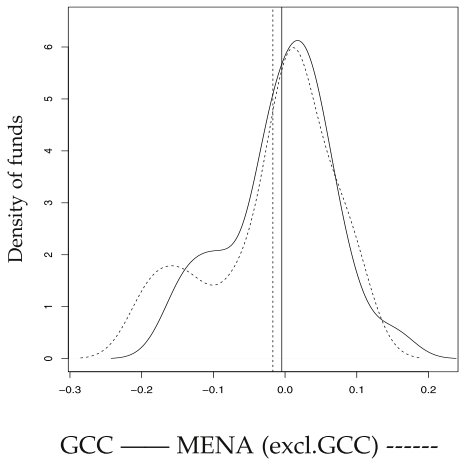

(c) All

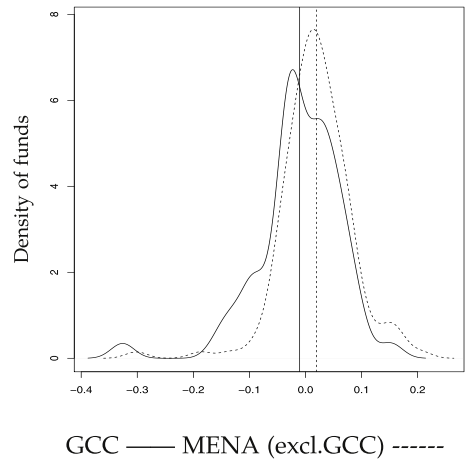

Fig. 6. Performance ( $\alpha$ ), GCC vs. MENA (excl.GCC), all period, Fama and French (1993) model.

Table 7

Results for mutual fund performance $(\alpha)$, crisis period (2006/1-2009/2).

$\begin{array}{lllllll}\begin{array}{l}\text { Number of } \\ \text { funds }\end{array} & \text { Model (1)(\%) } & \text { Model (2)(\%) } & \text { Model (3)(\%) } & \begin{array}{l}\text { Difference } \\ \text { Model } \\ (1)-\text { Model (2) }\end{array} & p \text {-value } & \begin{array}{l}\text { Difference } \\ \text { Model } \\ (1) \text {-Model (3) }\end{array}\end{array}$

(\%) (\%)

\begin{tabular}{|c|c|c|c|c|c|c|c|c|}
\hline \multicolumn{9}{|c|}{ Grouping by geographical investment focus } \\
\hline Egypt & 0 & - & - & - & - & - & - & - \\
\hline GCC $^{\mathrm{a}}$ & 26 & 4.2322 & 4.1657 & 3.8548 & 0.0665 & 0.985 & 0.3774 & 0.9150 \\
\hline Kuwait $^{\mathrm{b}}$ & 37 & -5.0736 & - & - & - & - & - & - \\
\hline MENA $^{a}$ & 6 & -7.7179 & -6.5568 & -5.1360 & -1.1611 & 0.9380 & -2.5820 & 0.8330 \\
\hline Morocco & 54 & 9.2580 & 14.0427 & 13.3710 & -4.7847 & 0.1260 & -4.1130 & 0.1500 \\
\hline Oman $^{\mathrm{b}}$ & 2 & 13.4238 & - & - & - & - & - & - \\
\hline Qatar & 0 & - & - & - & - & - & - & - \\
\hline Saudi Arabia ${ }^{b}$ & 36 & 8.5861 & - & - & - & - & - & - \\
\hline Tunisia $^{\mathrm{b}}$ & 4 & 5.1757 & - & - & - & - & - & - \\
\hline Turkey & 27 & -1.9547 & -0.9675 & -1.2717 & -0.9873 & 0.5650 & -0.6831 & 0.6860 \\
\hline United Arab Emirates & 8 & 6.5808 & 6.1752 & 5.9228 & 0.4056 & 0.8910 & 0.6580 & 0.8220 \\
\hline Total & 200 & 3.6623 & 7.0293 & 6.6487 & -3.3670 & 0.0490 & -2.9864 & 0.0560 \\
\hline \multicolumn{9}{|c|}{ Grouping by general investment zone } \\
\hline GCC-group ${ }^{c}$ & 109 & 2.8524 & 4.6385 & 4.3414 & -1.7861 & 0.4300 & -1.4890 & 0.5240 \\
\hline MENA-excluding GCC & 91 & 4.6324 & 7.9637 & 7.5504 & -3.3313 & 0.167 & -2.9180 & 0.1840 \\
\hline \multicolumn{9}{|c|}{ Grouping by Islamic orientation } \\
\hline Islamic & 55 & 3.5095 & 4.9508 & 4.7458 & -1.4413 & 0.6950 & -1.2363 & 0.7350 \\
\hline Conventional & 145 & 3.7203 & 7.4658 & 7.0483 & -3.7455 & 0.0550 & -3.3280 & 0.0600 \\
\hline \multicolumn{9}{|c|}{ Grouping by Islamic orientation (only GCC general investment zone) } \\
\hline Islamic & 52 & 3.7353 & 5.5016 & 5.0058 & -1.7663 & 0.6450 & -1.2705 & 0.7500 \\
\hline Conventional & 57 & 2.0469 & 3.6675 & 3.5939 & -1.6206 & 0.4860 & -1.5470 & 0.5040 \\
\hline
\end{tabular}

This table reports the results for the annualized mutual fund performance in the MENA region over the crisis period (January 2006-February 2009). Performance is estimated by regressing monthly fund returns in excess of the risk-free asset using three models. Model (1) uses two explanatory variables: a global benchmark representing investment in different markets in the fund's geographic area of influence, and a specific benchmark representing investment conditioned by the geographical focus defined by the fund, both measured in excess of the risk-free asset. Models (2) and (3) are extensions of Model (1) based on the models of Fama and French (1993) and Carhart (1997). In each panel, the number of funds and their average performance are reported, grouped by their geographical investment focus, their general investment zone, or their Islamic orientation. The lower panel reports the results for the funds grouped by their Islamic orientation, but focusing only on funds with the GCC as the general investment zone. The differences between Models and their corresponding $p$-values are also reported.

a GCC and MENA refer to those funds whose general investment zones are either GCC or MENA countries, but there is no specific information on the country where the investment takes place.

b Results for this country are only reported for Model (1) because of the lack of risk factor data.

c GCC-group refers to those funds investing in GCC countries.

d MENA-excluding GCC group refers to those funds investing in the MENA region, excluding GCC countries.

notably in the case of funds investing in Morocco (14.0427\% and $13.3710 \%$ ). This result might be pointing to mutual fund managers' ability to obtain positive value added in a scenario of higher volatility and crisis.

Model (1) shows that the funds investing in the GCC area perform less well than those in the rest of MENA countries (4.6324\% vs. 2.8524\%). Models (2) and (3) report similar results. Again, comparing Islamic and conventional funds in these areas is tricky because most of the funds investing in GCC countries are Islamic. Therefore, in the lower panel of Table 7 , as in Table 6, we report results for Islamic and conventional funds that invest exclusively in GCC countries. In this case, the 
Table 8

Results for mutual fund performance $(\alpha)$, recovery period (2009/3-2013/12).

\begin{tabular}{|c|c|c|c|c|c|c|c|}
\hline $\begin{array}{l}\text { Number of } \\
\text { funds }\end{array}$ & Model (1) (\%) & Model (2) (\%) & Model (3) (\%) & $\begin{array}{l}\text { Difference } \\
\text { Model } \\
\text { (1)-Model (2) } \\
\text { (\%) }\end{array}$ & $p$-value & $\begin{array}{l}\text { Difference } \\
\text { Model } \\
\text { (1)-Model (3) } \\
\text { (\%) }\end{array}$ & $p$-value \\
\hline
\end{tabular}

\begin{tabular}{|c|c|c|c|c|c|c|c|c|}
\hline \multicolumn{9}{|c|}{ Grouping by geographical investment focus } \\
\hline Egypt & 0 & - & - & - & - & - & - & - \\
\hline $\mathrm{GCC}^{\mathrm{a}}$ & 26 & -1.4774 & -1.4753 & -2.1789 & -0.0021 & 0.999 & 0.7015 & 0.694 \\
\hline Kuwait ${ }^{b}$ & 37 & -7.8808 & - & - & - & - & - & - \\
\hline MENA $^{a}$ & 6 & -1.2522 & -1.4510 & -1.9010 & 0.1988 & 0.950 & 0.6488 & 0.849 \\
\hline Morocco & 54 & 1.8127 & 1.0377 & 0.4474 & 0.7750 & 0.4880 & 1.3653 & 0.2340 \\
\hline Oman $^{\mathrm{b}}$ & 2 & -0.0306 & - & - & - & - & - & - \\
\hline Qatar & 0 & - & - & - & - & - & - & - \\
\hline Saudi Arabia ${ }^{b}$ & 36 & -2.8270 & - & - & - & - & - & - \\
\hline Tunisia $^{\mathrm{b}}$ & 4 & -5.1501 & - & - & - & - & - & - \\
\hline Turkey & 27 & -1.2886 & -1.8200 & -1.7690 & 0.5314 & 0.6370 & 0.4805 & 0.6720 \\
\hline United Arab Emirates & 8 & -0.7553 & 0.1269 & 0.0660 & -0.8822 & 0.6160 & -0.8213 & 0.6390 \\
\hline Total & 200 & -2.0145 & -0.3236 & -0.7532 & -1.6909 & 0.0120 & -1.2613 & 0.0660 \\
\hline \multicolumn{9}{|c|}{ Grouping by general investment zone } \\
\hline GCC-group ${ }^{c}$ & 109 & -4.0172 & -1.0983 & -1.6507 & -2.9190 & 0.0180 & -2.3666 & 0.0610 \\
\hline MENA-excluding GCC ${ }^{\mathrm{d}}$ & 91 & 0.3844 & -0.0208 & -0.4024 & 0.4052 & 0.6200 & 0.7868 & 0.3440 \\
\hline \multicolumn{9}{|c|}{ Grouping by Islamic orientation } \\
\hline Islamic & 55 & -3.1183 & -0.7044 & -1.4617 & -2.4138 & 0.1860 & -1.6565 & 0.3860 \\
\hline Conventional & 145 & -1.5958 & -0.2436 & -0.6043 & -1.3522 & 0.0630 & -0.9915 & 0.1770 \\
\hline \multicolumn{9}{|c|}{ Grouping by Islamic orientation (only GCC general investment zone) } \\
\hline Islamic & 52 & -3.1882 & -0.4704 & -1.2103 & -2.7178 & 0.1660 & -1.9780 & 0.3320 \\
\hline Conventional & 57 & -4.7735 & -1.8046 & -2.1461 & -2.9689 & 0.0480 & -2.6274 & 0.0750 \\
\hline
\end{tabular}

This table reports the results for the annualized mutual fund performance in the MENA region over the recovery period (March 2009-December 2013). Performance is estimated by regressing monthly fund returns in excess of the risk-free asset using three models. Model (1) uses two explanatory variables: a global benchmark representing investment in different markets in the fund's geographic area of influence, and a specific benchmark representing investment conditioned by the geographical focus defined by the fund, both measured in excess of the risk-free asset. Models (2) and (3) are extensions of Model (1) based on the models of Fama and French (1993) and Carhart (1997). In each panel, the number of funds and their average performance are reported, grouped by their geographical investment focus, their general investment zone, or their Islamic orientation. The lower panel reports the results for the funds grouped by their Islamic orientation, but focusing only on funds with the GCC as the general investment zone. The differences between Models and their corresponding $p$-values are also reported.

a GCC and MENA refer to those funds whose general investment zones are either GCC or MENA countries, but there is no specific information on the country where the investment takes place.

b Results for this country are only reported for Model (1) because of the lack of risk factor data.

c GCC-group refers to those funds investing in GCC countries.

d MENA-excluding GCC group refers to those funds investing in the MENA region, excluding GCC countries.

performance of Islamic funds almost doubles that of their conventional counterparts-in the column corresponding to Model (1), the average Islamic fund performance (3.7353\%) is $1.6884 \%$ higher than the average conventional fund performance (2.0469\%). Models (2) and (3) also lead to similar conclusions, as the average Islamic fund performance is $1.8342 \%$ and $1.4119 \%$ higher than the average conventional fund performance, respectively.

\subsubsection{Recovery period}

Results for the recovery period are reported in Table 8. Considering all investment areas, the average annualized performance is negative according to the three models $(-2.0145 \%,-0.3236 \%$, and $-0.7532 \%$ for Models (1)-(3), respectively). This suggests that managers find it more difficult to add value in a period of low volatility and moderate stock market growth; that is, a scenario with fewer opportunities to generate benefits to offset the costs attributable to management, which might not be flexible enough to adapt to changing scenarios. However, many tendencies are similar when the results for the two periods are compared (Tables 7 and 8), i.e. funds investing in the GCC area perform worse than the rest of the funds and, in addition, as shown in the lower panel, the tendency reverses for Islamic funds in GCC countries-in this area, the average performance of an Islamic fund is between $0.9359 \%$ and $1.5853 \%$ higher than that of a conventional mutual fund.

We also ran some tests to ascertain whether the differences observed between periods are statistically significant. We focus on the results of Model (1) so as to consider all the funds in the sample, and having verified in the previous analysis that there are no statistically significant differences in the fund performance obtained by considering the other models across the countries. As shown in Table 9, these differences are in all cases significant at the usual levels $(1 \%, 5 \%)$.

\subsection{Results for systematic risk}

We now compare the levels of systematic risk corresponding to the funds in each of the analyzed periods (Tables 10 and 11). Table 10 reports results for the first period and shows that, in general, the coefficient of the specific 
Table 9

Mutual fund performance $(\alpha)$, testing for the differences of means (comparing subperiods).

\begin{tabular}{llll}
\hline & \multicolumn{2}{l}{ Average performance (annualized, \%) } \\
\cline { 2 - 3 } & Crisis & Recovery & Difference (recovery-crisis) \\
\hline All funds & 3.66 & -2.01 & -5.68 \\
Grouping by general investment zone & & & \\
GCC-group $^{\mathrm{a}}$ & 2.85 & -4.02 & -6.87 \\
MENA-excluding GCC $^{\mathrm{b}}$ & 4.63 & 0.38 & -4.25 \\
Grouping by Islamic orientation & & & \\
Islamic & 3.51 & -3.12 & -6.63 \\
Conventional & 3.72 & -1.60 & -5.32 \\
Grouping by Islamic orientation (only GCC general investment zone) & & 0.0000 \\
Islamic & 3.74 & -3.19 & -6.92 \\
Conventional & 2.05 & -4.77 & -6.82 \\
\hline
\end{tabular}

This table presents the results reported in Tables 7 and 8 for the performance of mutual funds in the MENA region over the crisis (January 2006-February 2009) and the recovery period (March 2009-December 2013), respectively. Differences in the performance between periods and their corresponding $p$-values are also reported. Each panel presents the results for the average mutual fund performance, both overall and grouped by the funds' general investment zone, or their Islamic orientation. The lower panel reports the results for the funds grouped by their Islamic orientation, but focusing only on funds with the GCC as the general investment zone.

a GCC-group refers to those funds investing in GCC countries.

${ }^{\mathrm{b}}$ MENA-excluding GCC group refers to those funds investing in the MENA region, excluding GCC countries.

market factor $\left(\beta_{p, m}\right)$, or benchmark, reaches values below unity, regardless of the model used, or the country, zone, or Islamic orientation considered. Overall, the results of Model (1) show that the specific market factor is 0.8027 . Funds investing in MENA countries (excluding GCC) seem to have a higher $\beta_{p, m}(0.8288)$ than those investing in GCC countries $(0.7760)$. In addition, the sensitivity of Islamic funds to the specific market factor $\left(\beta_{p, m}\right)$ of Islamic funds $(0.7484)$ seems to be lower than that of the conventional mutual funds, regardless of the investment zone considered.

However, results for the coefficient of the general market factor $\left(\beta_{p, g}\right)$ suggest that it is not as relevant as the specific market factor (average value corresponding to 0.2090 for Model (1)). Yet this coefficient is higher for funds investing in GCC countries ( 0.3177 ) than for those investing in MENA countries (0.0787). Islamic funds also have higher $\beta_{p, g}$ than conventional mutual funds.

Table 11 reports the results for the second period. For Model (1), the value of the average $\beta$ with a specific market factor falls to 0.6593 . In contrast, the average $\beta$ with a general benchmark $(0.2199)$ increases slightly. When the two periods are compared, the $R^{2}$ is also worse, falling from 0.7652 to 0.7033 . We find the same evidence for Models (2) and (3). Thus, given that the most relevant factor is the specific market, we can conclude that funds have a weaker link to this factor during the second period; both the lower $\beta$ and lower $R^{2}$ point to this conclusion.

Table 12 shows the differences and significance for the betas corresponding to both periods when using Model (1). In most cases the differences in the average of the beta with the general benchmark are not significant. Only when the funds are grouped by general investment zone does the average of the funds outside the GCC increase the beta. With regard to the main systematic factor, i.e., beta with the specific benchmark, Table 12 shows how, on average, it fell significantly from the crisis period to the recovery period. This last result holds regardless of how funds are grouped.

Recall (Table 3) that the first period has higher volatility and negative return, whereas the second period shows less volatility and positive returns. Therefore, the weaker link with the market at times when it presents better behavior is the opposite management style to what might be expected from good managers. In other words, in a recovery period with moderate stock market growth, we should expect good managers to increase $\beta_{p, m}$, not diminish it. This would imply that the managers' timing has gone against the evolution of the market.

However, managers might not actually be carrying out active timing, but this is a passive outcome due to asymmetric behavior of the assets, as suggested by Matallín-Sáez et al. (2015). These authors show that in bullish markets (such as those in our second period) the correlation among assets is lower, but it increases in bearish times, and with higher volatility (as in our first period). This would suggest asymmetric behavior in the assets' betas-higher in bearish periods and lower in bullish periods-which would help to explain our findings.

In addition, as indicated in the lower rows of the right panel in Table 12, when comparing the results for Islamic and conventional funds we observe that the effect commented on above is higher for Islamic funds. The beta (for the specific benchmark) varies between -0.1344 for Islamic funds and -0.0838 for conventional funds. Since the Islamic stocks are usually more stable and less correlated with the market than other stocks (see, for instance (see, for instance Askari et al., 2010), as correlation increases (in higher volatility times and market downturns), this asymmetric effect might be exacerbated. As a consequence, the higher value added of Islamic fund managers as compared to their conventional peers might be eroded for this reason, contributing to shrink the gap between the two performances $(1.69 \%$ in the first period and $1.59 \%$ in the second) from the data in the lower panels of Tables 7 and 8, respectively. 
Table 10

Results for systematic risk ( $\beta$ ), crisis period (2006/1-2009/2)

\begin{tabular}{|c|c|c|c|c|c|c|c|c|c|c|}
\hline & \multirow{2}{*}{$\begin{array}{l}\text { Number of } \\
\text { funds }\end{array}$} & \multicolumn{3}{|l|}{ Model (1) } & \multicolumn{3}{|l|}{ Model (2) } & \multicolumn{3}{|l|}{ Model (3) } \\
\hline & & $\begin{array}{l}\text { Average beta } \\
\text { with general } \\
\text { benchmark } \\
\left(\beta_{p, g}\right)\end{array}$ & $\begin{array}{l}\text { Average beta } \\
\text { with specific } \\
\text { benchmark } \\
\left(\beta_{p, m}\right)\end{array}$ & $R^{2}$ & $\begin{array}{l}\text { Average beta } \\
\text { with general } \\
\text { benchmark } \\
\left(\beta_{p, g}\right)\end{array}$ & $\begin{array}{l}\text { Average beta } \\
\text { with specific } \\
\text { benchmark } \\
\left(\beta_{p, m}\right)\end{array}$ & $R^{2}$ & $\begin{array}{l}\text { Average beta } \\
\text { with general } \\
\text { benchmark } \\
\left(\beta_{p, g}\right)\end{array}$ & $\begin{array}{l}\text { Average beta } \\
\text { with specific } \\
\text { benchmark } \\
\left(\beta_{p, m}\right) \\
\end{array}$ & $R^{2}$ \\
\hline \multicolumn{11}{|c|}{ Grouping by geographical investment focus } \\
\hline Egypt & 0 & - & - & - & - & - & - & - & - & - \\
\hline $\mathrm{GCC}^{\mathrm{a}}$ & 26 & 0.7795 & - & 0.6342 & 0.7789 & - & 0.6875 & 0.7813 & - & 0.7059 \\
\hline Kuwait $^{\mathrm{b}}$ & 37 & 0.0998 & 0.7643 & 0.7494 & - & - & - & - & - & - \\
\hline MENA $^{a}$ & 6 & 0.7385 & - & 0.6050 & 0.7378 & - & 0.6422 & 0.7460 & - & 0.6690 \\
\hline Morocco & 54 & 0.0244 & 0.8453 & 0.7027 & 0.1125 & 0.8760 & 0.7588 & 0.1169 & 0.8693 & 0.7616 \\
\hline $\mathrm{Oman}^{\mathrm{b}}$ & 2 & 0.2165 & 0.8437 & 0.8381 & - & - & - & - & - & - \\
\hline Qatar & 0 & - & - & - & - & - & - & - & - & - \\
\hline Saudi Arabia & 36 & 0.2632 & 0.7812 & 0.8614 & - & - & - & - & - & - \\
\hline Tunisia $^{\mathrm{b}}$ & 4 & 0.1942 & 0.4232 & 0.5424 & - & - & - & - & - & - \\
\hline Turkey & 27 & 0.0236 & 0.8558 & 0.9373 & -0.0182 & 0.8875 & 0.9608 & -0.0248 & 0.8884 & 0.9625 \\
\hline United Arab Emirates & 8 & 0.0956 & 0.7896 & 0.8848 & 0.0898 & 0.8179 & 0.8938 & 0.0908 & 0.8153 & 0.8943 \\
\hline Total & 200 & 0.2090 & 0.8027 & 0.7652 & 0.2560 & 0.8743 & 0.7917 & 0.2575 & 0.8702 & 0.7987 \\
\hline \multicolumn{11}{|c|}{ Grouping by general investment zone } \\
\hline GCC-group ${ }^{c}$ & 109 & 0.3177 & 0.7760 & 0.7705 & 0.6168 & 0.8179 & 0.7360 & 0.6188 & 0.8153 & 0.7502 \\
\hline MENA-excluding GCC & 91 & 0.0787 & 0.8288 & 0.7588 & 0.1151 & 0.8798 & 0.8135 & 0.1163 & 0.8757 & 0.8176 \\
\hline \multicolumn{11}{|c|}{ Grouping by Islamic orientation } \\
\hline Islamic & 55 & 0.4366 & 0.7484 & 0.7629 & 0.4366 & 0.5568 & 0.7246 & 0.8018 & 0.5537 & 0.7417 \\
\hline Conventional & 145 & 0.1226 & 0.8170 & 0.7661 & 0.1429 & 0.8779 & 0.8058 & 0.1432 & 0.8738 & 0.8106 \\
\hline \multicolumn{11}{|c|}{ Grouping by Islamic orientation (only GCC general investment zone) } \\
\hline Islamic & 52 & 0.4185 & 0.7484 & 0.7742 & 0.8049 & 0.5568 & 0.7442 & 0.8130 & 0.5537 & 0.7632 \\
\hline Conventional & 57 & 0.2258 & 0.7961 & 0.7672 & 0.4051 & 0.8552 & 0.7268 & 0.4004 & 0.8526 & 0.7356 \\
\hline
\end{tabular}

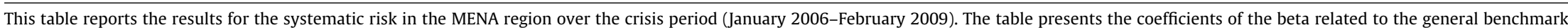

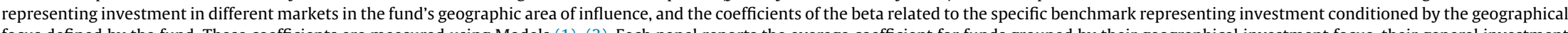

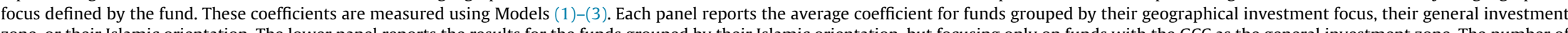

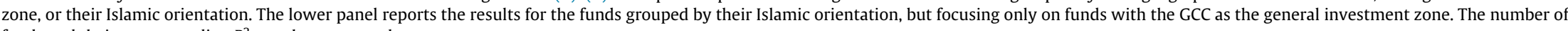
funds and their corresponding $R^{2}$ are also presented.

a GCC and MENA refer to those funds whose general investment zones are either GCC or MENA countries, but there is no specific information on the country where the investment takes place.

b Results for this country are only reported for Model (1) because of the lack of risk factor data.

c GCC-group refers to those funds investing in GCC countries.

d MENA-excluding GCC group refers to those funds investing in the MENA region, excluding GCC countries. 
Table 11

Results for systematic risk ( $\beta$ ), recovery period (2009/3-2013/12).

\begin{tabular}{|c|c|c|c|c|c|c|c|c|c|c|}
\hline & \multirow[b]{2}{*}{$\begin{array}{l}\text { Number of } \\
\text { funds }\end{array}$} & \multicolumn{3}{|l|}{ Model (1) } & \multicolumn{3}{|l|}{ Model (2) } & \multicolumn{3}{|l|}{ Model (3) } \\
\hline & & $\begin{array}{l}\text { Average beta } \\
\text { with general } \\
\text { benchmark } \\
\left(\beta_{p, g}\right)\end{array}$ & $\begin{array}{l}\text { Average beta } \\
\text { with specific } \\
\text { benchmark } \\
\left(\beta_{p, m}\right)\end{array}$ & $R^{2}$ & $\begin{array}{l}\text { Average beta } \\
\text { with general } \\
\text { benchmark } \\
\left(\beta_{p, g}\right)\end{array}$ & $\begin{array}{l}\text { Average beta } \\
\text { with specific } \\
\text { benchmark } \\
\left(\beta_{p, m}\right)\end{array}$ & $R^{2}$ & $\begin{array}{l}\text { Average beta } \\
\text { with general } \\
\text { benchmark } \\
\left(\beta_{p, g}\right)\end{array}$ & $\begin{array}{l}\text { Average beta } \\
\text { with specific } \\
\text { benchmark } \\
\left(\beta_{p, m}\right)\end{array}$ & $R^{2}$ \\
\hline \multicolumn{11}{|c|}{ Grouping by geographical investment focus } \\
\hline Egypt & 0 & - & - & - & - & - & - & - & - & - \\
\hline $\mathrm{GCC}^{\mathrm{a}}$ & 26 & 0.7371 & - & 0.6001 & 0.7461 & - & 0.6262 & 0.7571 & - & 0.6423 \\
\hline Kuwait $^{\mathrm{b}}$ & 37 & 0.2200 & 0.5144 & 0.6813 & - & - & - & - & - & - \\
\hline MENA $^{a}$ & 6 & 0.8388 & - & 0.6695 & 0.8483 & - & 0.6836 & 0.8498 & - & 0.6937 \\
\hline Morocco & 54 & 0.1132 & 0.5777 & 0.6260 & 0.1310 & 0.6100 & 0.6640 & 0.1521 & 0.6289 & 0.6945 \\
\hline Oman $^{\mathrm{b}}$ & 2 & 0.0264 & 0.7222 & 0.8379 & - & - & - & - & - & - \\
\hline Qatar & 0 & - & - & - & - & - & - & - & - & - \\
\hline Saudi Arabiab & 36 & 0.0292 & 0.8259 & 0.7661 & - & - & _- & - & - & - \\
\hline Tunisia $^{\mathrm{b}}$ & 4 & 0.1277 & 0.3306 & 0.3513 & - & - & - & - & - & - \\
\hline Turkey & 27 & 0.1394 & 0.8348 & 0.9298 & 0.0010 & 0.8885 & 0.9573 & 0.0019 & 0.8877 & 0.9584 \\
\hline United Arab Emirates & 8 & 0.0189 & 0.6881 & 0.7830 & -0.0002 & 0.7042 & 0.7913 & 0.0394 & 0.6921 & 0.7957 \\
\hline Total & 200 & 0.2199 & 0.6593 & 0.7033 & 0.2611 & 0.7029 & 0.7307 & 0.2757 & 0.7131 & 0.7488 \\
\hline \multicolumn{11}{|c|}{ Grouping by general investment zone } \\
\hline GCC-group ${ }^{C}$ & 109 & 0.2620 & 0.6712 & 0.7003 & 0.5705 & 0.7042 & 0.6650 & 0.5882 & 0.6921 & 0.6784 \\
\hline MENA-excluding $\mathrm{GCC}^{\mathrm{d}}$ & 91 & 0.1694 & 0.6477 & 0.7069 & 0.1402 & 0.7028 & 0.7564 & 0.1536 & 0.7152 & 0.7764 \\
\hline \multicolumn{11}{|c|}{ Grouping by Islamic orientation } \\
\hline Islamic & 55 & 0.3492 & 0.6150 & 0.6416 & 0.7067 & 0.4746 & 0.5985 & 0.7170 & 0.4724 & 0.6160 \\
\hline Conventional & 145 & 0.1709 & 0.6710 & 0.7267 & 0.1675 & 0.7055 & 0.7585 & 0.1831 & 0.7158 & 0.7767 \\
\hline \multicolumn{11}{|c|}{ Grouping by Islamic orientation (only GCC general investment zone) } \\
\hline Islamic & 52 & 0.3256 & 0.6150 & 0.6476 & 0.6965 & 0.4746 & 0.6064 & 0.7081 & 0.4724 & 0.6239 \\
\hline Conventional & 57 & 0.2040 & 0.7123 & 0.7483 & 0.4288 & 0.7370 & 0.7310 & 0.4534 & 0.7235 & 0.7397 \\
\hline
\end{tabular}

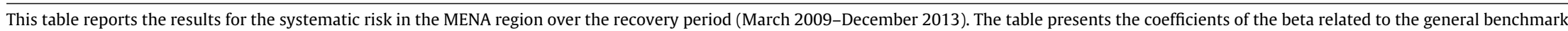

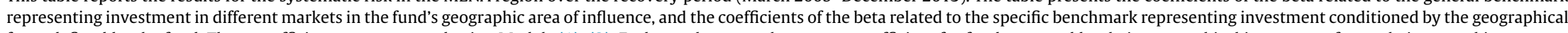

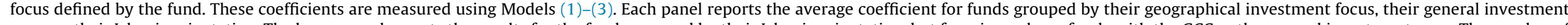

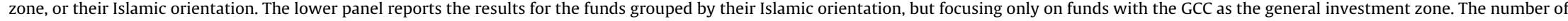
funds and their average $R^{2}$ are also reported.

a GCC and MENA refer to those funds whose general investment zones are either GCC or MENA countries, but there is no specific information on the country where the investment takes place.

${ }^{b}$ Results for this country are only reported for Model (1) because of the lack of risk factor data.

c GCC-group refers to those funds investing in GCC countries.

d MENA-excluding GCC group refers to those funds investing in the MENA region, excluding GCC countries. 
Table 12

Systematic risk $(\beta)$, testing for the differences of means (comparing subperiods).

\begin{tabular}{|c|c|c|c|c|c|c|c|c|}
\hline & \multicolumn{4}{|c|}{ Average beta with general benchmark ( $\left.\beta_{p, g}, \%\right)$} & \multicolumn{4}{|c|}{ Average beta with specific benchmark } \\
\hline & Crisis & Recovery & $\begin{array}{l}\text { Difference } \\
\text { (recovery-crisis) }\end{array}$ & $p$-value & Crisis & Recovery & $\begin{array}{l}\text { Difference } \\
\text { (recovery-crisis) }\end{array}$ & $p$-value \\
\hline All funds & 0.2090 & 0.2199 & 0.0109 & 0.7173 & 0.8027 & 0.6593 & -0.1433 & 0.0000 \\
\hline \multicolumn{9}{|c|}{ Grouping by general investment zone } \\
\hline GCC-group ${ }^{\mathrm{a}}$ & 0.3177 & 0.2620 & -0.0557 & 0.2238 & 0.7760 & 0.6712 & -0.1047 & 0.0022 \\
\hline MENA-excluding $\mathrm{GCC}^{\mathrm{b}}$ & 0.0787 & 0.1694 & 0.0907 & 0.0048 & 0.8288 & 0.6477 & -0.1810 & 0.0000 \\
\hline \multicolumn{9}{|c|}{ Grouping by Islamic orientation } \\
\hline Islamic & 0.4366 & 0.3492 & -0.0875 & 0.2047 & 0.7484 & 0.6150 & -0.1334 & 0.0155 \\
\hline Conventional & 0.1226 & 0.1709 & 0.0482 & 0.0915 & 0.8170 & 0.6710 & -0.1459 & 0.0000 \\
\hline \multicolumn{9}{|c|}{ Grouping by Islamic orientation (only GCC general investment zone) } \\
\hline Islamic & 0.4185 & 0.3256 & -0.0929 & 0.1864 & 0.7484 & 0.6150 & -0.1334 & 0.0155 \\
\hline Conventional & 0.2258 & 0.2040 & -0.0218 & 0.7005 & 0.7961 & 0.7123 & -0.0838 & 0.0496 \\
\hline
\end{tabular}

This table presents the results reported in Tables 10 and 11 for the systematic risk of mutual funds in the MENA region over the crisis (January 2006 -February 2009) and the recovery period (March 2009-December 2013), respectively. The table reports the coefficients of the beta related to the general benchmark representing investment in different markets in the fund's geographic area of influence, and the coefficients of the beta related to the specific benchmark representing investment conditioned by the geographical focus defined by the fund. The differences in the results between periods and corresponding $p$-values are also presented. Each panel displays the results for the average coefficients, overall or grouped by the funds' by their general investment zone, or their Islamic orientation. The lower panel reports the results for the funds grouped by their Islamic orientation, but focusing only on funds with the GCC as the general investment zone.

a GCC-group refers to those funds investing in GCC countries.

b MENA-excluding GCC group refers to those funds investing in the MENA region, excluding GCC countries.

Table 13

Results for SMB, HML, and UMD factors, crisis period (2006/1-2009/2).

\begin{tabular}{|c|c|c|c|c|c|c|}
\hline & \multirow{2}{*}{$\begin{array}{l}\text { Number of } \\
\text { funds }\end{array}$} & \multicolumn{2}{|l|}{ Model (2) } & \multicolumn{3}{|l|}{ Model (3) } \\
\hline & & $\begin{array}{l}\text { Average beta } \\
\text { with SMB } \\
\text { factor }\left(\beta_{p, S M B}\right)\end{array}$ & $\begin{array}{l}\text { Average beta } \\
\text { with HML } \\
\text { factor }\left(\beta_{p, H M L}\right)\end{array}$ & $\begin{array}{l}\text { Average beta } \\
\text { with SMB } \\
\text { factor }\left(\beta_{p, S M B}\right)\end{array}$ & $\begin{array}{l}\text { Average beta with } \\
\text { HML factor }\left(\beta_{p, H M L}\right)\end{array}$ & $\begin{array}{l}\text { Average beta with } \\
\text { momentum factor } \\
\left(\beta_{p, U M D}\right)\end{array}$ \\
\hline Total & 121 & 0.1795 & 0.1322 & 0.1690 & 0.1276 & -0.0345 \\
\hline \multicolumn{7}{|c|}{ Grouping by general investment zone } \\
\hline GCC-group & 34 & -0.0588 & -0.0039 & -0.0544 & 0.0085 & 0.0311 \\
\hline MENA-excluding GCC $^{\mathrm{b}}$ & 87 & 0.2726 & 0.1853 & 0.2563 & 0.1741 & -0.0601 \\
\hline \multicolumn{7}{|c|}{ Grouping by Islamic orientation } \\
\hline Islamic & 21 & -0.0183 & 0.0291 & -0.0012 & 0.0597 & 0.1262 \\
\hline Conventional & 100 & 0.2210 & 0.1538 & 0.2047 & 0.1418 & -0.0682 \\
\hline \multicolumn{7}{|c|}{ Grouping by Islamic orientation (only GCC general investment zone) } \\
\hline Islamic & 18 & -0.1058 & -0.0016 & -0.0992 & 0.0195 & 0.1439 \\
\hline Conventional & 16 & -0.0059 & -0.0064 & -0.0040 & -0.0040 & -0.0958 \\
\hline
\end{tabular}

This table reports the results for the betas related to the SMB, HML, and UMD factors in the MENA region over the crisis period (January 2006-February 2009). SMB, HML and UMD are the returns on the size (Small Minus Big), book-to-market (High Minus Low), and momentum (Up Minus Down) factor mimicking portfolios, respectively. The coefficients on the betas are estimated using Models (2) and (3). Each panel presents the number of funds and the average coefficient of the betas, overall or grouped by the funds' general investment zone, or their Islamic orientation. The lower panel reports the results for the funds grouped by Islamic orientation, but focusing only on funds with the GCC as the general investment zone.

a GCC-group refers to those funds investing in GCC countries.

b MENA-excluding GCC group refers to those funds investing in the MENA region, excluding GCC countries.

\subsection{Results for size, book-to-market, and momentum factors}

Tables 13 and 14 show the results of the size, book-to-market, and momentum factors considered in Models (2) and (3). Table 13 shows the results for the first period, and Table 14, the second period. This analysis considers 121 funds for which all the factors are available.

Table 13 shows that, according to Model (3), funds investing in MENA countries (excluding GCC) are slightly more sensitive to the size $(0.2563$ vs. -0.0544$)$ and to the book-to-market $(0.1741$ vs. 0.0085$)$ factors than funds investing in GCC countries. However, their momentum factor exposure is negative $\left(\beta_{p, U M D}=-0.0601\right)$, in contrast to that of the funds investing in GCC countries (0.0311). Nonetheless, this value for the funds investing in GCC countries is an average effect due to the negative exposure of the conventional funds $(-0.0958)$ and the positive effect on the Islamic funds (0.1439) of the momentum factor. Thus, the coefficient on the momentum factor seems to be higher for Islamic funds than for conventional funds. 
Table 14

Results for SMB, HML, and UMD factors, recovery period (2009/3-2013/12).

\begin{tabular}{|c|c|c|c|c|c|c|}
\hline & \multirow{2}{*}{$\begin{array}{l}\text { Number of } \\
\text { funds }\end{array}$} & \multicolumn{2}{|l|}{ Model (2) } & \multicolumn{3}{|l|}{ Model (3) } \\
\hline & & $\begin{array}{l}\text { Average beta } \\
\text { with SMB } \\
\text { factor }\left(\beta_{p, S M B}\right)\end{array}$ & $\begin{array}{l}\text { Average beta } \\
\text { with HML } \\
\text { factor }\left(\beta_{p, H M L}\right)\end{array}$ & $\begin{array}{l}\text { Average beta } \\
\text { with SMB } \\
\text { factor }\left(\beta_{p, S M B}\right)\end{array}$ & $\begin{array}{l}\text { Average beta } \\
\text { with HML } \\
\text { factor }\left(\beta_{p, H M L}\right)\end{array}$ & $\begin{array}{l}\text { Average beta with } \\
\text { momentum factor } \\
\left(\beta_{p, U M D}\right)\end{array}$ \\
\hline Total & 121 & 0.1671 & -0.0033 & 0.1771 & -0.0013 & 0.1999 \\
\hline \multicolumn{7}{|c|}{ Grouping by general investment zone } \\
\hline GCC-group ${ }^{\mathrm{a}}$ & 34 & 0.0503 & -0.0032 & 0.0553 & 0.0114 & 0.3512 \\
\hline MENA-excluding GCC ${ }^{\mathrm{b}}$ & 87 & 0.2127 & -0.0033 & 0.2247 & -0.0062 & 0.1408 \\
\hline \multicolumn{7}{|c|}{ Grouping by Islamic orientation } \\
\hline Islamic & 21 & 0.0767 & -0.0066 & 0.0715 & -0.0097 & 0.3254 \\
\hline Conventional & 100 & 0.1860 & -0.0026 & 0.1992 & 0.0005 & 0.1736 \\
\hline \multicolumn{7}{|c|}{ Grouping by Islamic orientation (only GCC general investment zone) } \\
\hline Islamic & 18 & 0.0675 & 0.0052 & 0.0679 & 0.0105 & 0.4343 \\
\hline Conventional & 16 & 0.0310 & -0.0125 & 0.0411 & 0.0124 & 0.2577 \\
\hline
\end{tabular}

This table reports the results for the betas related to the SMB, HML, and UMD factors in MENA region over the recovery period (March 2009-December 2013). SMB, HML and UMD are the returns on the size (Small Minus Big), book-to-market (High Minus Low), and momentum (Up Minus Down) factor mimicking portfolios, respectively. The coefficients on the betas are estimated using Models (2) and (3). Each panel presents the number of funds and the average coefficient of the betas, in overall or grouping the funds by their general investment zone, or their Islamic orientation. The lower panel of the table reports the results for the funds grouped by their Islamic orientation, but focusing only on funds with the GCC as the general investment zone.

a GCC-group refers to those funds investing in GCC countries.

b MENA-excluding GCC group refers to those funds investing in the MENA region, excluding GCC countries.

Table 14 shows that funds investing in MENA countries (excluding GCC) have a lower coefficient on the HML factor $(-0.0062)$ during the recovery period, but their exposure to the momentum factor increases $(0.1408)$. However, this coefficient is again lower than that of the funds investing in GCC countries (0.3254). Islamic funds also have higher coefficients, especially in GCC countries $(0.4343)$.

The differences in the mean of these coefficients between periods are reported in Table 15, which also shows whether these differences are statistically significant. Almost none of the funds considered differs significantly in its exposure to the size factor during the two periods. Only funds investing in MENA countries (excluding GCC) seem to differ in their exposure to the book-to-market factor, and their coefficient diminishes during the second period. Finally, conventional funds seem to have a significantly higher coefficient on momentum factor during the recovery period, while the difference in the mean of this coefficient for Islamic funds, albeit positive, is not statistically significant.

\subsection{Determinants of mutual fund performance}

The analysis reported in the preceding paragraphs provides a broad view on the performance of the mutual funds investing in the MENA region. This is a relevant context and our results on the performance of the MENA region financial systems contribute to the scarce number of studies focusing on this region and dealing with related issues.

In this section we attempt to understand the influence of some variables as a source of differences in mutual fund efficiencies. In this regard, although the literature is remarkable (see, for instance Bär et al., 2011; Golec, 1996; Atkinson et al., 2003; Niessen and Ruenzi, 2007; Hambrick and Mason, 1984; Malhotra et al., 2007; Porter and Trifts, 1998; Wermers, 2003; Gottesman and Morey, 2006; Ippolito, 1989; Elton et al., 1993a, among others), we will make an attempt to synthesize it, splitting the analysis of determinants into three main sources of variation, or types of information that may influence fund performance, namely: (i) some fund characteristics; (ii) some fund management characteristics; and (iii) environmental factors such as the wealth of the region where investments take place.

There is an expanding body of literature on the two first factors, i.e., the effects of some fund and fund management characteristics (see, for a recent example Yin, 2016). We consider both the age (AGE) and size (SIZE) of the funds to be relevant characteristics for analysis. In the case of AGE, the evidence is mixed: authors like Hu and Chang (2008) found negative impact of fund age (performance deteriorates with the age of the fund), whereas others found the evidence was not significant (Chen et al., 2004; Ferreira et al., 2013).

The evidence for fund size is also mixed, as revealed in Bertin and Prather (2009). Chen et al. (2004) found that the impact is negative, since small funds outperform their larger counterparts. This result was also found by Ferreira et al. (2013) for a sample of US mutual funds, although this negative effect could not be extended to non-US funds. In other relevant and influential studies such as Carhart (1997) a positive relationship can arise between fund size and performance due to the benefits of economies of scale. The methodologies we use are particularly appropriate for this type of outputs, since the existence of varying coefficients for different quantiles of the conditional distribution of performance might be underlying an "inconclusive" link. 
Table 15

SMB, HML, and UMD factors, testing for the differences of means (comparing subperiods).

\begin{tabular}{|c|c|c|c|c|c|c|c|c|c|c|c|c|}
\hline & \multicolumn{4}{|c|}{ Average beta with SMB factor $\left(\beta_{p, S M B}\right)$} & \multicolumn{4}{|c|}{ Average beta with HML factor $\left(\beta_{p, H M L}\right)$} & \multicolumn{4}{|c|}{ Average beta with momentum factor ( $\left.\beta_{p, U M D}\right)$} \\
\hline & Crisis & Recovery & $\begin{array}{l}\text { Difference } \\
\text { (recovery- } \\
\text { crisis) }\end{array}$ & $p$-value & Crisis & Recovery & $\begin{array}{l}\text { Difference } \\
\text { (recovery- } \\
\text { crisis) }\end{array}$ & $p$-value & Crisis & Recovery & $\begin{array}{l}\text { Difference } \\
\text { (recovery- } \\
\text { crisis) }\end{array}$ & $p$-value \\
\hline All funds & 0.1690 & 0.1771 & 0.0081 & 0.8087 & 0.1276 & -0.0013 & -0.1289 & 0.0000 & -0.0345 & 0.1999 & 0.2344 & 0.0000 \\
\hline \multicolumn{13}{|c|}{ Grouping by general investment zone } \\
\hline GCC-group ${ }^{\mathrm{a}}$ & -0.0544 & 0.0553 & 0.1097 & 0.0148 & 0.0085 & 0.0114 & 0.0029 & 0.9421 & 0.0311 & 0.3512 & 0.3201 & 0.0286 \\
\hline MENA-excludin & $c^{b} 0.2563$ & 0.2247 & -0.0316 & 0.4114 & 0.1741 & -0.0062 & -0.1804 & 0.0000 & -0.0601 & 0.1408 & 0.2009 & 0.0000 \\
\hline \multicolumn{13}{|c|}{ Grouping by Islamic orientation } \\
\hline $\begin{array}{l}\text { Islamic } \\
\text { Sonventional }\end{array}$ & -0.0992 & 0.0679 & $\begin{array}{l}0.1671 \\
0.041\end{array}$ & 0.0218 & 0.0195 & 0.0105 & -0.0091 & 0.8898 & 0.1439 & 0.4343 & 0.2904 & 0.2462 \\
\hline
\end{tabular}

This table presents the results reported in Tables 13 and 14 for the betas related to the SMB, HML, and UMD factors in the MENA region over the crisis (January 2006-February 2009) and the recovery period

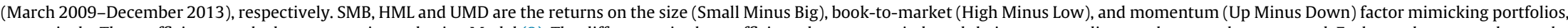
respectively. The coefficients on the betas are estimated using Model (3). The differences in the coefficients between periods and their corresponding $p$-values are also presented. Each panel presents the results

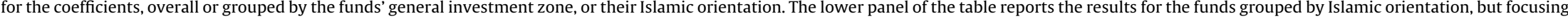
only on funds with the GCC as the general investment zone.

a GCC-group refers to those funds investing in GCC countries.

b MENA-excluding GCC group refers to those funds investing in the MENA region, excluding GCC countries. 
The other two fund characteristics considered, costs (COSTS) and survivorship bias (SO) are more closely related to managerial factors, especially the former. The role of mutual fund managers and their contribution to performance has been considered in previous research studies which date back to Golec (1996), who documented that the mutual fund manager's characteristics determine the fund's performance in relation to the risk and costs incurred.

However, results in the literature regarding the impact of costs are also diverse. For instance, Ippolito (1989) found that actively managed funds outperform their passive counterparts; Elton et al. (1993b), in contrast, found that mutual fund managers underperformed passive portfolios (i.e., the higher the fees, the lower the performance), and argued that the results shown in Ippolitos (1989) results were driven by non-benchmark stocks.

The third group of variables we consider might have an impact on mutual fund performance is related to the environment surrounding the fund which, ultimately, impacts on its efficiency. The literature has analyzed environmental variables such as market conditions (Shrider, 2009), market volatility (Cao et al., 2008), social factors marked by new investment trends (such as, for instance, ethical funds Bauer et al., 2005), investor "sentiments" (Indro, 2004; Beaumont et al., 2008), or the more general changing economic conditions (Ferson and Schadt, 1996).

We follow some recent literature analyzing Islamic banking and finance issues (see, for instance Naifar, 2016) and focus on a broad set of socioeconomic variables. Apart from fund orientation (Islamic or conventional, ORIENTATION) and investment focus (MENA/GCC) considered in previous sections, we have added a further five variables reported by the Economic Freedom of the World Annual Report 2015, ${ }^{8}$ namely, size of the government (area1), legal system and property rights (area2), sound money (area3), freedom to trade internationally (area4), and regulation (area5). These five variables are constructed from information on a variety of issues, including:

Size of the government (area1): (i) government consumption; (ii) transfers and subsidies; (iii) government enterprises and investment; (iv) top marginal income tax rate; (v) top marginal income and payroll tax rate; (vi) top marginal tax rate.

Legal system \& property rights (area2): (i) judicial independence; (ii) impartial courts; (iii) protection of property rights; (iv) military interference in rule of law and politics; (v) integrity of the legal system; (vi) legal enforcement of contracts; (vii) regulatory restrictions on the sale of real property; (viii) reliability of police; (ix) business costs of crime.

Sound money (area3): (i) money growth; (ii) standard deviation of inflation; (iii) inflation: most recent year; (iv) freedom to own foreign currency bank accounts.

Freedom to trade internationally (area4): (i) revenue from trade taxes (\% of trade sector); (ii) mean tariff rate; (iii) standard deviation of tariff rates; (iv) tariffs; (v) non-tariff trade barriers; (vi) compliance costs of importing and exporting; (vii) regulatory trade barriers; (viii) black market exchange rates; (ix) foreign ownership/investment restrictions; (x) capital controls; (xi) freedom of foreigners to visit; (xii) controls of the movement of capital and people.

Regulation (area5): (i) ownership of banks; (ii) private sector credit; (iii) interest rate controls/negative real interest rates; (iv) credit market regulations; (v) hiring regulations and minimum wage; (vi) hiring and firing regulations; (vii) centralized collective bargaining; (viii) hours regulations; (ix) mandated cost of worker dismissal; (x) conscription; (xi) labor market regulations; (xii) administrative requirements; (xiii) bureaucracy costs; (xiv) "starting a business"; (xv) extra payments/bribes/favoritism; (xvi) licensing restrictions; (xvii) tax compliance; (xviii) business regulations.

The methodology for the analysis in this section includes the possibility that mutual fund performance distributions might have non-normal or heavy-tailed shapes. In such cases, it could be misleading to use regression techniques focusing on the "average effect for the average fund." Here, we consider quantile regression (see, for instance Koenker, 2001), which allows us to analyze the links between the set of likely determinants of performance at different points in the conditional distribution of mutual fund performances. ${ }^{9}$

Therefore, the regression quantiles specify the $\tau^{\text {th }}$ quantile of the conditional distribution of mutual fund performance, $\hat{\theta}_{i}$ is the variable containing the performance of the fund, and $\boldsymbol{z}$ a linear function of the covariates. Following Koenker and Bassett (1978) we may carry out the estimation by minimizing the following equation:

$$
\operatorname{Min}_{\boldsymbol{\beta} \in \mathbb{R}^{k}} \sum_{i \in\left\{i: \hat{\theta}_{i} \geq \boldsymbol{z}^{\prime} \boldsymbol{\beta}\right\}} \tau\left|\hat{\theta}_{i}-\boldsymbol{z}^{\prime} \boldsymbol{\beta}\right|+\sum_{i \in\left\{i: \hat{\theta}_{i}<\boldsymbol{z}^{\prime} \boldsymbol{\beta}\right\}}(1-\tau)\left|\hat{\theta}_{i}-\boldsymbol{z}^{\prime} \boldsymbol{\beta}\right|
$$

\footnotetext{
${ }^{8}$ See http://www.freetheworld.com/datasets_efw.html, accessed June 29th, 2016.

${ }^{9}$ Quantile regression is more informative than OLS for several reasons. For instance, some covariates might be more relevant for the highest performing funds than for the average fund. In addition, quantile (Coad and Rao, 2008).
} 
Table 16

Determinants of performance $(\alpha)$, regression quantiles (whole period), Model (1).

\begin{tabular}{|c|c|c|c|c|c|c|c|c|c|}
\hline \multicolumn{10}{|c|}{ Dependent variable: $\alpha$ (Model (1)) } \\
\hline \multirow[t]{2}{*}{ Covariates } & \multicolumn{3}{|l|}{$\begin{array}{l}\text { All funds } \\
\text { Quantile }(\tau)\end{array}$} & \multicolumn{3}{|l|}{$\begin{array}{l}\text { Islamic funds } \\
\text { Quantile }(\tau)\end{array}$} & \multicolumn{3}{|c|}{$\begin{array}{l}\text { Conventional funds } \\
\text { Quantile }(\tau)\end{array}$} \\
\hline & $\tau=0.25$ & $\tau=0.50$ & $\tau=0.75$ & $\tau=0.25$ & $\tau=0.50$ & $\tau=0.75$ & $\tau=0.25$ & $\tau=0.50$ & $\tau=0.75$ \\
\hline (Intercept) & $\begin{array}{l}0.5723 \\
(-1.0407 \\
-0.1460)\end{array}$ & $\begin{array}{l}-0.1469 \\
(-0.3758 \\
0.1109)\end{array}$ & $\begin{array}{l}0.1489 \\
(-1.6776, \\
0.4895)\end{array}$ & $\begin{array}{l}-0.0202 \\
(-0.8903 \\
1.1265)\end{array}$ & $\begin{array}{l}0.1151 \\
(-0.1476, \\
2.4854)\end{array}$ & $\begin{array}{l}0.4313(0.0017, \\
5.0766)\end{array}$ & $\begin{array}{l}0.0032 \\
(-0.2489 \\
0.1405)\end{array}$ & $\begin{array}{l}0.0495 \\
(-0.1011, \\
0.1292)\end{array}$ & $\begin{array}{l}0.0495 \\
(-0.1454, \\
0.2215)\end{array}$ \\
\hline$A G E$ & $\begin{array}{l}-0.0004 \\
(-0.0039 \\
0.0001)\end{array}$ & $\begin{array}{l}-0.0012 \\
(-0.0016 \\
0.0003)\end{array}$ & $\begin{array}{l}0.0006 \\
(-0.0002 \\
0.0002)\end{array}$ & $\begin{array}{l}-0.0060 \\
(-0.01320 \\
0.0012)\end{array}$ & $\begin{array}{l}-0.0024 \\
(-0.0118 \\
-0.0014)\end{array}$ & $\begin{array}{l}-0.0042 \\
(-0.0100 \\
-0.0001)\end{array}$ & $\begin{array}{l}-0.0002 \\
(-0.0034 \\
0.0022)\end{array}$ & $\begin{array}{l}-0.0003 \\
(-0.0015 \\
0.0015)\end{array}$ & $\begin{array}{l}0.0012 \\
(-0.0006 \\
0.0022)\end{array}$ \\
\hline SIZE & $\begin{array}{l}0.0032(0.0002 \\
0.0082)\end{array}$ & $\begin{array}{l}0.0016 \\
(-0.0017 \\
0.0045)\end{array}$ & $\begin{array}{l}0.0001 \\
(-0.0046 \\
0.0079)\end{array}$ & $\begin{array}{l}0.0087(0.0046 \\
0.0349)\end{array}$ & $\begin{array}{l}0.0095(0.0046 \\
0.0221)\end{array}$ & $\begin{array}{l}0.0124 \\
(-0.0046 \\
0.0293)\end{array}$ & $\begin{array}{l}-0.0014 \\
(-0.0069 \\
0.0069)\end{array}$ & $\begin{array}{l}-0.0014 \\
(-0.0051, \\
0.0019)\end{array}$ & $\begin{array}{l}-0.0014 \\
(-0.0065 \\
0.0044)\end{array}$ \\
\hline COSTS & $\begin{array}{l}0.6276(0.1686 \\
1.5621)\end{array}$ & $\begin{array}{l}0.4648 \\
(-0.5977 \\
0.8753)\end{array}$ & $\begin{array}{l}0.1277 \\
(-1.399 \\
0.5331)\end{array}$ & $\begin{array}{l}9.0774(2.4827 \\
12.7646)\end{array}$ & $\begin{array}{l}8.2701(3.3342 \\
10.8688)\end{array}$ & $\begin{array}{l}6.3844(1.2981, \\
14.2819)\end{array}$ & $\begin{array}{l}0.1474 \\
(-0.8131 \\
1.5451)\end{array}$ & $\begin{array}{l}0.0768 \\
(-0.5952 \\
0.5256)\end{array}$ & $\begin{array}{l}-0.6755 \\
(-1.5853 \\
0.1254)\end{array}$ \\
\hline SO & $\begin{array}{l}0.0720(0.0154 \\
0.1076)\end{array}$ & $\begin{array}{l}0.0219(0.0151 \\
0.0488)\end{array}$ & $\begin{array}{l}0.0222(0.0091 \\
0.0478)\end{array}$ & $\begin{array}{l}0.0371 \\
(-0.0282 \\
0.1184)\end{array}$ & $\begin{array}{l}0.0249 \\
(-0.0300 \\
0.0722)\end{array}$ & $\begin{array}{l}0.0131 \\
(-0.0472 \\
0.0431)\end{array}$ & $\begin{array}{l}0.0615(0.0105 \\
0.1243)\end{array}$ & $\begin{array}{l}0.0315(0.0107 \\
0.0556)\end{array}$ & $\begin{array}{l}0.0315(0.0011 \\
0.0409)\end{array}$ \\
\hline area 1 & $\begin{array}{l}-0.0441 \\
(-0.0702 \\
-0.0267)\end{array}$ & $\begin{array}{l}-0.0572 \\
(-0.0825 \\
-0.0263)\end{array}$ & $\begin{array}{l}-0.0402 \\
(-0.1296 \\
0.0043)\end{array}$ & $\begin{array}{l}-0.1351 \\
(-1.5753 \\
-0.0570)\end{array}$ & $\begin{array}{l}-0.1399 \\
(-0.7003 \\
-0.0534)\end{array}$ & $\begin{array}{l}-0.0551 \\
(-0.4650 \\
0.4184)\end{array}$ & $\begin{array}{l}-0.0322 \\
(-0.0557 \\
-0.0124)\end{array}$ & $\begin{array}{l}-0.0379 \\
(-0.0700 \\
-0.0178)\end{array}$ & $\begin{array}{l}-0.0195 \\
(-0.1008 \\
-0.0074)\end{array}$ \\
\hline area 2 & $\begin{array}{l}0.1988(0.1485 \\
0.2446)\end{array}$ & $\begin{array}{l}0.1111(0.0777 \\
0.1383)\end{array}$ & $\begin{array}{l}0.04360 \\
(0.0047 \\
0.2670)\end{array}$ & $\begin{array}{l}0.0430 \\
(-0.2188 \\
0.2016)\end{array}$ & $\begin{array}{l}0.0071 \\
(-0.2073 \\
0.1463)\end{array}$ & $\begin{array}{l}-0.0622 \\
(-0.1060 \\
0.4472)\end{array}$ & $\begin{array}{l}0.1326(0.0749 \\
0.2029)\end{array}$ & $\begin{array}{l}0.1233(0.0781 \\
0.1498)\end{array}$ & $\begin{array}{l}0.0868 \\
(0.0111,0 . \\
1505)\end{array}$ \\
\hline area 3 & $\begin{array}{l}0.0176 \\
(-0.0537 \\
0.0517)\end{array}$ & $\begin{array}{l}-0.0349 \\
(-0.0562 \\
0.0103)\end{array}$ & $\begin{array}{l}-0.0729 \\
(-0.0894 \\
0.0016)\end{array}$ & $\begin{array}{l}-0.0281 \\
(-0.1589 \\
0.0620)\end{array}$ & $\begin{array}{l}-0.0313 \\
(-0.3036 \\
0.0081)\end{array}$ & $\begin{array}{l}-0.0618 \\
(-0.7122 \\
0.0305)\end{array}$ & $\begin{array}{l}-0.0189 \\
(-0.0506 \\
0.0348)\end{array}$ & $\begin{array}{l}-0.0155 \\
(-0.0552 \\
0.0099)\end{array}$ & $\begin{array}{l}-0.0133 \\
(-0.1003 \\
0.0217)\end{array}$ \\
\hline area 4 & $\begin{array}{l}0.0661(0.0332 \\
0.1143)\end{array}$ & $\begin{array}{l}0.1240(0.0702, \\
0.1836)\end{array}$ & $\begin{array}{l}0.1255(0.0431, \\
0.2663)\end{array}$ & $\begin{array}{l}0.2567(0.0382 \\
1.9433)\end{array}$ & $\begin{array}{l}0.2461(0.1062, \\
1.0755)\end{array}$ & $\begin{array}{l}0.0898 \\
(-0.5748 \\
2.0244)\end{array}$ & $\begin{array}{l}0.0753(0.0392, \\
0.1185)\end{array}$ & $\begin{array}{l}0.0792(0.0445 \\
0.1557)\end{array}$ & $\begin{array}{l}0.0528(0.0122, \\
0.2305)\end{array}$ \\
\hline Area5 & $\begin{array}{l}-0.1754 \\
(-0.2269 \\
-0.1359)\end{array}$ & $\begin{array}{l}-0.1272 \\
(-0.1438 \\
-0.0775)\end{array}$ & $\begin{array}{l}-0.0748 \\
(-0.1911 \\
0.0434)\end{array}$ & $\begin{array}{l}-0.1715 \\
(-0.5954, \\
\text { infeasible) }\end{array}$ & $\begin{array}{l}-0.1358 \\
(-0.7610 \\
0.0184)\end{array}$ & $\begin{array}{l}0.0105 \\
\text { (infeasible, } \\
0.3683 \text { ) }\end{array}$ & $\begin{array}{l}-0.1627 \\
(-0.2539 \\
-0.1126)\end{array}$ & $\begin{array}{l}-0.1556 \\
(-0.1651 \\
-0.1163)\end{array}$ & $\begin{array}{l}-0.1099 \\
(-0.1804 \\
-0.0583)\end{array}$ \\
\hline
\end{tabular}

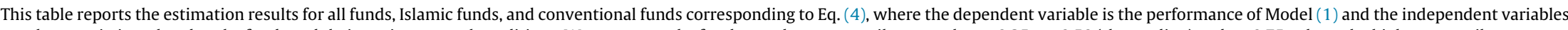

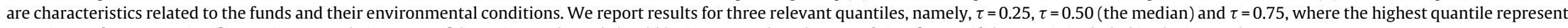
superior performance. Significance is reported via 95\% confidence intervals, and should be interpreted as absence of significance if the zero is included in the interval. 
where $k$ is the number of explanatory variables, $\tau$ represents the vector containing each quantile (and the vector of coefficients to be estimated), and $\boldsymbol{\beta}$ will differ depending on the particular quantile.

Results are reported in Table $16 .^{10}$ The rows refer to the determinants considered, and the columns represent each quantile of the conditional distribution of mutual fund performance: the columns on the left $(\tau=.25)$ represent the worst performance, and those on the right ( $\tau=.75$ ), the best performance. The numbers in brackets represent the $95 \%$ confidence intervals and, therefore, if the zero is included it means that the variable (for the regression quantile considered) is not significant-i.e., significantly different from zero.

Table 16 shows that the significance, sign and magnitude of the impact depends partly on the quantile considered, thus corroborating the relevance of this approach and the previous "mixed" findings in the literature. For instance, the impact of fund age (AGE) on performance is negative, but generally not significant-the zero is always contained in the confidence interval. In contrast, the impact of fund size (SIZE) is positive, irrespective of the quantile, but it is significant only for the worst funds $(\tau=.25)$. This positive impact is also positive when variables related to managers' performance such as COSTS are taken into account-i.e., the fees and other costs involved in managing the fund. In this case, although the effect is positive, it is also only significant at the lowest quantiles $(\tau=.25)$. This positive influence might therefore indicate that, for this region, previous results in the literature are corroborated in the sense that actively managed funds outperform their passive counterparts. The survivorship bias variable (SO), a dummy variable taking the value of 1 for funds that survived by the end of the period, is positive and significant throughout, regardless of the quantile considered. Thus, non-surviving funds perform less well than surviving funds. These results, based on the effect fund characteristics have on mutual fund performance, are in line with the previous literature (see Ferreira et al., 2013; Rohleder et al., 2011, among others).

The effects of the environmental variables based on the Economic Freedom of the World Annual Report are also reported in Table 16. The variables related to the size of government (area1) and regulation (area5) have a negative effect on mutual fund performance, whereas in the case of the legal system and property rights (area2), sound money (area3) and freedom to trade internationally (area4) the effect is positive. The results are quite robust across quantiles, with some exceptions where significance is lost for some (upper quantiles in the case of area 1 and area5), or all quantiles-the case of "sound money". However, the general finding would indicate that those countries with more regulation and more important government roles do not create the most favorable environment for mutual fund performance to excel. In contrast, a strong legal system (including judicial independence, impartial courts, protection of property rights, legal enforcement of contracts, etc.), as well as better conditions to trade internationally, have a strong and significant effect on fund performance.

Finally, we also ran quantile regressions separately for Islamic and conventional funds, reported in Table 16 . Despite being generally similar to results for all funds together, these results are not entirely coincidental and in some areas the differences are notable. The effect of fund-related characteristics size (SIZE) and costs (COSTS) differ greatly, since in the case of Islamic funds the effect is positive and significant across quantiles (with the exception of the upper quantile for size). This suggests, particularly in the case of costs, that active fund management (generally associated to higher costs) has a much stronger effect on performance, revealing how important it is for this particular type of funds to be skillfully managed. This might suggest that although Islamic funds face more stringent constraints than their conventional counterparts, if their managers are sufficiently skilled (i.e., if they are able to add value) they will better handle these tighter constraints and, ultimately, outperform other unconstrained investments-which turns out to be the case.

\section{Conclusions}

In the context of the increasing popularity of Islamic financial products, the present study compares the performance of Islamic and conventional mutual funds in the Middle East and North Africa region, broadly defined to include Turkey. To this end, we utilize several models from the literature on mutual fund performance. First, we use a linear model that adjusts mutual fund returns to different market factors according to their geographic investment focus. The first is a general market factor and the second, a specific market factor, but both avoid bias introduced by omitting relevant benchmarks. We also use the two models proposed in the influential studies by Fama and French (1993) and Carhart (1997), using the two market factors explained above. These models have rarely been considered when analyzing performance of funds investing in the MENA region. The sample is free of survivorship bias and consists of 336 mutual funds from January 2006 to December 2013.

We consider the study to be pertinent for a variety of reasons. First, there are theoretical arguments supporting the view that Islamic funds and other types of constrained investments (SRI for example), might exhibit more stable patterns in turbulent times, from both financial and socioeconomic points of view (Askari et al., 2010; Abdelsalam et al., 2014a). If we factor in the growth of these types of funds (especially Islamic) since the beginning of the 2000s (Abdelsalam et al., 2014b), they offer a particularly interesting field of research.

Second, these reasons have motivated several studies comparing the relative performance of Islamic funds with either conventional or other types of constrained investments such as SRI. However, the previous literature does not usually consider only the funds investing in the MENA region. This region has become important from both a financial perspective

\footnotetext{
${ }_{10}$ Results are restricted to the basic model and to the entire period for space reasons. Results are available for Models (2) and (3) and crisis and recovery periods upon request.
} 
(due to the stock market liberalization initiatives in several MENA countries) and a socioeconomic viewpoint (due to the revolts in the area).

Third, conducting an analysis by subperiods allows us to factor in bear and bull markets and, therefore, to assess more precisely whether Islamic funds are more stable-i.e., we can test the hypothesis of whether their performance is, in general, comparable to that of conventional funds, and more resilient during financial downturns.

Results can be explored from a variety of perspectives. Specifically, we report results grouping mutual funds according to their geographic investment focus (country), their general investment zone (GCC or MENA, excluding GCC), or orientation (Islamic or conventional). In general, we find notable discrepancies among the performances of the funds investing in the area. These discrepancies are quite apparent when evaluating the performance for funds investing in each particular country, in specific groups of countries (GCC/rest of MENA), or according to the Islamic orientation. The analysis by subperiods is also pertinent, since these results change according to the subperiod considered.

Firstly, our results show that when mutual funds are grouped by general investment zone, mutual funds of the GCC region perform, on average, worse than the funds from the rest of the MENA zone. This evidence holds both for the analysis of the entire sample and for the two subsample periods, crisis and recovery; this difference is most notable in the second period.

Secondly, we compared the performance of Islamic and conventional mutual funds. We differentiate between regions and orientations, a useful distinction because conventional funds perform (on average) better than their Islamic counterparts when considering the entire MENA region, but the opposite results are found for the GCC countries. Since most Islamic funds belong to the GCC region, a direct comparison of the two fund types may be biased by the better performance of other countries in the MENA region. Therefore, a more appropriate comparison would be to focus only on the GCC, where the vast majority of Islamic funds invest. In the latter case, the performance of Islamic funds is better than conventional funds, and this finding holds for the analysis of the entire period and for the two subperiods.

Thirdly, we compared the performance of the mutual funds between crisis and recovery periods. In line with previous literature on conventional mutual funds we find that mutual funds perform better in bad states than in good states. This evidence also holds for Islamic mutual funds. Therefore, although the literature indicates that Islamic finance is more stable and less sensitive to conventional markets, when compared with mutual fund performance in good and bad states, Islamic and conventional funds show similar patterns.

Fourthly, we analyzed mutual fund systematic risk. The results show that the most important systematic risk factor is the local or specific benchmark. In the aggregate, the funds investing in the GCC region are slightly less risky than the rest of the funds in the MENA region, and in turn, Islamic funds are slightly less risky than conventional funds. Considered jointly, mutual funds are less risky in the recovery than in crisis periods, which could be interpreted as incorrect market timing. When grouped by orientation, the systematic risk reduction was greater in Islamic than in conventional funds, a result that could be partly explained by the more stable behavior of the Islamic assets. Note also that the Islamic funds' exposure to the book-to-market and momentum factors does not seem to differ significantly between crisis and recovery periods, unlike those of the conventional funds. In addition, although some differences are found, results are robust across all the performance measurement models used-namely, the basic model and the extensions by Fama and French (1993) and Carhart (1997).

Finally, we explored the sources of mutual fund performance heterogeneity using quantile regression, given that it is more informative than OLS on the differential effects performance has on the conditional distribution, and is robust to deviations from normality. We used variables related to fund characteristics usually considered in the mutual fund performance literature: size, age, costs and survivorship bias; and some environmental variables: the size of the government, legal system and property rights, sound money, freedom to trade internationally, and regulation. We also used quantile regression to analyze Islamic and conventional funds separately. Given the high number of variables and their diversity, results can be explored from multiple angles. Two of the variables related to specific mutual fund characteristics are particularly relevant (significant), namely, costs (generally arising from fund management) and survivorship bias. The separate analysis based on fund orientation shows that the importance of costs is mostly driven by the Islamic funds, for which the effect is positive and significant throughout quantiles, whereas the effect for conventional funds is non-significant. The explanations for this vary, but they highlight the importance of skillful management for Islamic funds and show that, despite tighter investment constraints, when Islamic fund managers are able to add value, the funds investing in this region can outperform their conventional counterparts. However, it is important to note that this ideally requires a strong legal system (including judicial independence, impartial courts, protection of property rights, legal enforcement of contracts, etc.), and better international trading conditions, given the positive and significant effect these variables have on fund performance.

\section{References}

Abdelsalam, O., Duygun, M., Matallín-Sáez, J.C., Tortosa-Ausina, E., 2014a. Do ethics imply persistence? The case of Islamic and socially responsible funds. J. Bank. Finance 40, 182-194.

Abdelsalam, O., Fethi, M.D., Matallín, J.C., Tortosa-Ausina, E., 2014b. On the comparative performance of socially responsible and Islamic mutual funds. J. Econ. Behav. Organ. 103, S108-S128.

Abdullah, F., Hassan, T., Mohamad, S., 2007. Investigation of performance of Malaysian Islamic unit trust funds: comparison with conventional unit trust funds. Manag. Finance 33 (2), 142-153.

Achy, L., 2001. Financial liberalization, savings, investment, and growth in MENA countries. Res. Middle East Econ. 6, 67-94.

Akoum, I., Graham, M., Kivihaho, J., Nikkinen, J., Omran, M., 2012. Co-movement of oil and stock prices in the GCC region: a wavelet analysis. Q. Rev. Econ. Finance 52 (4), 385-394. 
Ali, S.S., 2005. Islamic capital market products: Developments and challenges. Occasional Paper 9 (1425H/2005). Islamic Research and Training Institute (IRTI), Islamic Development Bank Group, Jeddah, Saudi Arabia.

Aloui, R., Aïssa, M.S.B., Nguyen, D.K., 2011. Global financial crisis, extreme interdependences, and contagion effects: the role of economic structure? J Bank. Finance $35(1), 130-141$.

Askari, H., Iqbal, Z., Krichene, N., Mirakhor, A., 2010. The Stability of Islamic Finance. Wiley Finance, Wiley, Singapore.

Atkinson, S., Baird, S., Frye, M., 2003. Do female mutual fund managers manage differently? J. Financial Res. 26 (1), 1-18.

Bauer, R., Koedijk, K., Otten, R., 2005. International evidence on ethical mutual fund performance and investment style. J. Bank. Finance 29 (7), $1751-1767$.

Beaumont, R., van Daele, M., Frijns, B., Lehnert, T., Muller, A., 2008. Investor sentiment, mutual fund flows and its impact on returns and volatility. Manag. Finance 34 (11), 772-785.

Bertin, W.J., Prather, L., 2009. Management structure and the performance of funds of mutual funds. J. Bus. Res. 62 (12), 1364-1369.

Bär, M., Kempf, A., Ruenzi, S., 2011. Is a team different from the sum of its parts? Evidence from mutual fund managers. Rev. Finance 15, 359-396.

Cao, C., Chang, E.C., Wang, Y., 2008. An empirical analysis of the dynamic relationship between mutual fund flow and market return volatility. J. Bank. Finance 32 (10), 2111-2123.

Carhart, M.M., 1997. On persistence in mutual fund performance. J. Finance 52 (1), 57-82.

Chaney, E., 2013. Revolt on the Nile: economic shocks, religion, and political power. Econometrica 81 (5), 2033-2053.

Chaney, E., Akerlof, G.A., Blaydes, L., Spring 2012. Democratic change in the Arab World, past and present. Brookings Papers on Economic Activity., pp. 363-414.

Chen, J., Hong, H., Huang, M., Kubik, J.D., 2004. Does fund size erode mutual fund performance? The role of liquidity and organization. Am. Econ. Rev. 94 (5), 1276-1302.

Coad, A., Rao, R., 2008. Innovation and firm growth in high-tech sectors: a quantile regression approach. Res. Policy 37 (4), 633-648.

Daniel, K., Grinblatt, M., Titman, S., Wermers, R., 1997. Measuring mutual fund performance with characteristic-based benchmarks. J. Finance 52 (3), 1035-1058.

De Souza, A., Lynch, A.W., 2012. Does mutual fund performance vary over the business cycle? Working Paper 18137. National Bureau of Economic Research, Cambridge, MA.

Dungey, M., Zhumabekova, D., 2001. Testing for contagion using correlations: some words of caution. Pacific Basin Working Paper PB01-09. Federal Reserve Bank of San Francisco, San Francisco, CA.

Elfakhani, S.M., Hassan, M.K., Sidani, Y.M., 2007. Islamic mutual funds. In: Hasan, M.K., Lewis, M.K. (Eds.), The Handbook of Islamic Banking. Edward Elgar Publishing, Cheltenham, pp. 256-273 (Chapter 16).

Elton, E.J., Gruber, M.J., Das, S., Hlavka, M., 1993a. Efficiency with costly information: a reinterpretation of evidence from managed portfolios. Rev. Financial Stud. $6(1), 1-22$.

Elton, E.J., Gruber, M.J., Das, S., Hlavka, M., 1993b. Efficiency with costly information: a reinterpretation of evidence from managed portfolios. Rev. Financial Stud. 6 (1), 1-22.

Erragraguy, E., Revelli, C., 2015. Should Islamic investors consider SRI criteria in their investment strategies? Finance Res. Lett. 14, 11-19.

Fama, E.F., French, K.R., 1993. Common risk factors in the returns on stocks and bonds. J. Financial Econ. 33 (1), 3-56.

Ferreira, M.A., Keswani, A., Miguel, A.F., Ramos, S.B., 2013. The determinants of mutual fund performance: a cross-country study. Rev. Finance 17 (2), 483-525.

Ferson, W.E., Schadt, R.W., 1996. Measuring fund strategy and performance in changing economic conditions. J. Finance 51 (2), $425-461$.

Gentzoglanis, A., 2007. Financial integration, regulation and competitiveness in Middle East and North Africa countries. Manag. Finance 33 (7), 461-476.

Glode, V., 2011. Why mutual funds “underperform”. J. Financial Econ. 99 (3), 546-559.

Golec, J., 1996. The effects of mutual fund managers' characteristics on their portfolio performance, risk and fees. Financial Serv. Rev. 5 (2), 133-148.

Gottesman, A.A., Morey, M.R., 2006. Manager education and mutual fund performance. J. Empir. Finance 13 (2), 145-182.

Graham, M., Kiviaho, J., Nikkinen, J., Omran, M., 2013. Global and regional co-movement of the MENA stock markets. J. Econ. Bus. 65, 86-100.

Guo, F., Chen, C.R., Huang, Y.S., 2011. Markets contagion during financial crisis: a regime-switching approach. Int. Rev. Econ. Finance 20 (1), $95-109$.

Hambrick, D.C., Mason, P.A., 1984. Upper echelons: the organization as a reflection of its top managers. Acad. Manag. Rev. 9 (2), $193-206$.

Hayat, R., Kraeussl, R., 2011. Risk and return characteristics of Islamic equity funds. Emerg. Mark. Rev. 12 (2), 189-203.

Hu, J., Chang, T., 2008. Decomposition of mutual fund underperformance. Appl. Financial Econ. Lett. 4 (5), 363-367.

Indro, D.C., 2004. Does mutual fund flow reflect investor sentiment? J. Behav. Finance 5 (2), 105-115.

Ippolito, R.A., 1989. Efficiency with costly information: a study of mutual fund performance, 1965-1984. Q. J. Econ. 104 (1), 1-23.

Kacperczyk, M., Van Nieuwerburgh, S., Veldkamp, L., 2014. Time-varying fund manager skill. J. Finance 69 (4), 1455-1484.

Kenourgios, D., Samitas, A., Paltalidis, N., 2011. Financial crises and stock market contagion in a multivariate time-varying asymmetric framework. J. Int. Financial Mark. Inst. Money 21 (1), 92-106.

Khaldi, K., Hamdouni, A., 2011. Islamic financial intermediation: equity, efficiency and risk. Int. Res. J. Finance Econ. 65, 145-160.

Khan, F., 2010. How "Islamic" is Islamic banking? J. Econ. Behav. Organ. 76 (3), 805-820.

Khatkhatay, M.H., Nisar, S., 2007. Shari'ah compliant equity investments: an assessment of current screening norms. Islamic Econ. Stud. 15, 47-76.

Knutsen, C.H., 2014. Income growth and revolutions. Soc. Sci. Q. 95 (4), 920-937.

Koenker, R., 2001. Quantile regression. J. Econ. Perspect. 15 (4), 143-156.

Koenker, R., Bassett, G., 1978. Regression quantiles. Econometrica 46 (1), 33-50.

Kosowski, R., 2011. Do mutual funds perform when it matters most to investors? US mutual fund performance and risk in recessions and expansions. Q. J. Finance 1 (3), 607-664.

Longstaff, F.A., 2010. The subprime credit crisis and contagion in financial markets. J. Financial Econ. 97 (3), 436-450.

Malhotra, D.K., Martin, R., Russel, P., 2007. Determinants of cost efficiencies in the mutual fund industry. Rev. Financial Econ. 16 (4), $323-334$.

Malik, A., Awadallah, B., 2013. The economics of the Arab Spring. World Dev. 45, 296-313.

Matallín-Sáez, J.C., 2006. Seasonality, market timing and performance amongst benchmarks and mutual fund evaluation. J. Bus. Finance Account. 33 (9-10), 1484-1507.

Matallín-Sáez, J.C., Moreno, D., Rodriguez, R., 2015. Why timing is perverse? Eur. J. Finance 21 (15), 1334-1356.

Merdad, H., Hassan, M.K., Alhenawi, Y., 2010. Islamic Versus conventional mutual funds performance in Saudi Arabia: A case study. Journal of King Abdulaziz University: Islamic Economics 23 (2).

Naceur, S.B., Ghazouani, S., Omran, M., 2008. Does stock market liberalization spur financial and economic development in the MENA region? J. Comp. Econ. $36(4), 673-693$.

Naifar, N., 2016. Do global risk factors and macroeconomic conditions affect global Islamic index dynamics? A quantile regression approach. Q. Rev. Econ. Finance 61, 29-39.

Neaime, S., 2005. Financial market integration and macroeconomic volatility in the MENA region: an empirical investigation. Rev. Middle East Econ. Finance 3 (3), 231-255.

Neaime, S., 2012. The global financial crisis, financial linkages and correlations in returns and volatilities in emerging MENA stock markets. Emerg. Mark. Rev. 13 (3), 268-282.

Niessen, A., Ruenzi, S., 2007. Sex Matters: Gender Differences in a Professional Setting, Available at SSRN: http://ssrn.com/abstract4966243.

Olson, D., Zoubi, T.A., 2008. Using accounting ratios to distinguish between Islamic and conventional banks in the GCC region. Int. J. Account. 43, 45-65.

Pástor, L., Stambaugh, R.F., 2002. Investing in equity mutual funds. J. Financial Econ. 63 (3), 351-380.

Porter, G.E., Trifts, J.W., 1998. Performance persistence of experienced mutual fund managers. Financial Serv. Rev. 7 (1), 57-68.

Please cite this article in press as: El-Masry, A.A., et al., Environmental conditions, fund characteristics, and Islamic orientation: An analysis of mutual fund performance for the MENA region. J. Econ. Behav. Organ. (2016), http://dx.doi.org/10.1016/j.jebo.2016.10.015 
Rohleder, M., Scholz, H., Wilkens, M., 2011. Survivorship bias and mutual fund performance: relevance, significance, and methodical differences. Rev. Finance 15 (2), 441-474.

Sekkat, K., 2014. Inter-state tensions and regional integration: could the Arab Spring initiate a virtuous circle? Contemp. Arab Aff. 7 (3), $363-379$.

Sharpe, W.F., 1992. Asset allocation: management style and performance measurement. J. Portf. Manag. 18 (2), 7-19.

Shrider, D.G., 2009. Running from a bear: how poor stock market performance affects the determinants of mutual fund flows. J. Bus. Finance Account. 36 (7-8), 987-1006.

Silverman, B.W., 1986. Density Estimation for Statistics and Data Analysis. Chapman and Hall, London.

Wermers, R. (2003). Is money really 'smart'? New evidence on the relation between mutual fund flows, manager behavior, and performance persistence. Available at SSRN: http://ssrn. com/abstract414420.

Williams, G., Zinkin, J., 2010. Islam and CSR: a study of the compatibility between the tenets of Islam and the UN global compact. J. Bus. Ethics 91 (4), 519-533.

Winckler, O., 2013. The "Arab Spring": Socioeconomic aspects. Middle East Policy 20 (4), 68-87.

Yin, C., 2016. The optimal size of hedge funds: conflict between investors and fund managers. J. Finance 71 (4), 1857-1894. 